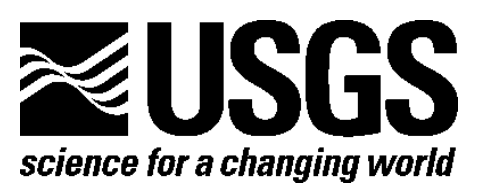

\title{
Spatial and Stratigraphic Distribution of Water in Oil Shale of the Green River Formation Using Fischer Assay, Piceance Basin, Northwestern Colorado
}

Open-File Report 2014-1059

U.S. Department of the Interior U.S. Geological Survey 


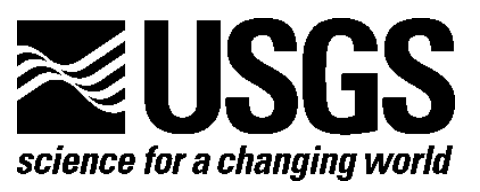

\section{Spatial and Stratigraphic Distribution of Water in Oil Shale of the Green River Formation Using Fischer Assay, Piceance Basin, Northwestern Colorado}

By Ronald C. Johnson, Tracey J. Mercier, and Michael E. Brownfield

Open-File Report 2014-1059

U.S. Department of the Interior

U.S. Geological Survey 


\section{U.S. Department of the Interior \\ SALLY JEWELL, Secretary}

\section{U.S. Geological Survey \\ Suzette M. Kimball, Acting Director}

U.S. Geological Survey, Reston, Virginia: 2014

For more information on the USGS—-the Federal source for science about the Earth, its natural and living resources, natural hazards, and the environment-visit http://www.usgs.gov or call 1-888-ASK-USGS

For an overview of USGS information products, including maps, imagery, and publications, visit $h t t p: / / w w w . u s g s . g o v / p u b p r o d$

To order this and other USGS information products, visit $h$ ttp://store.usgs.gov

Suggested citation:

Johnson, R.C., Mercier, T.J., and Brownfield, M.E., 2014, Spatial and stratigraphic distribution of water in oil shale of the Green River Formation using Fischer Assay, Piceance Basin, northwestern Colorado: U.S. Geological Survey Open-File Report 2014-1059, 57 p., http://dx.doi.org/10.3133/ofr20141059.

ISSN 2331-1258 (online)

Any use of trade, firm, or product names is for descriptive purposes only and does not imply endorsement by the U.S. Government.

Although this information product, for the most part, is in the public domain, it also may contain copyrighted materials as noted in the text. Permission to reproduce copyrighted items must be secured from the copyright owner. 


\section{Contents}

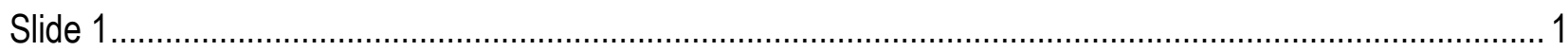

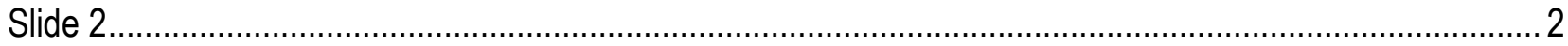

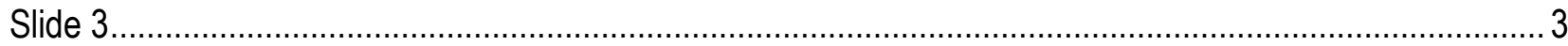

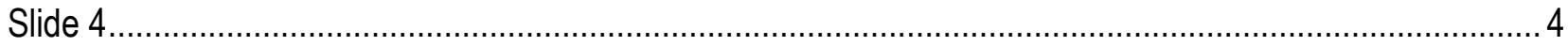

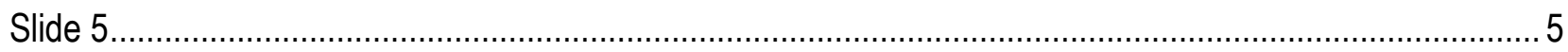

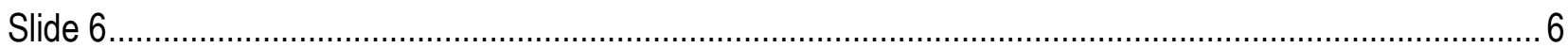

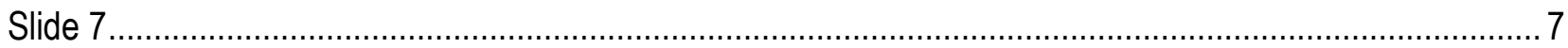

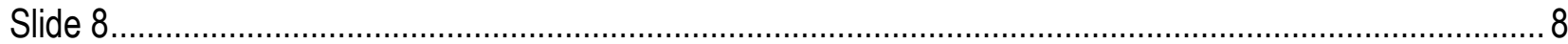

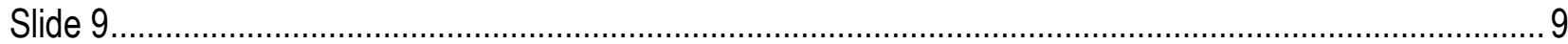

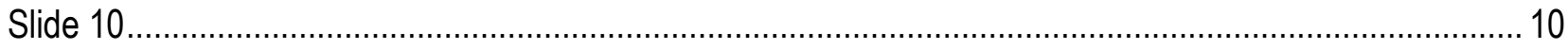

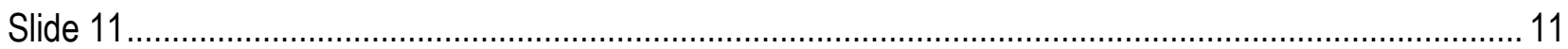

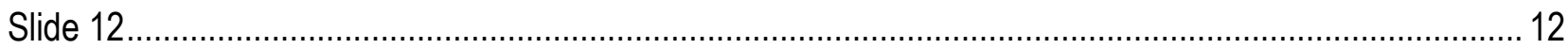

Slide 13

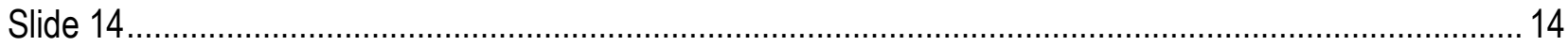

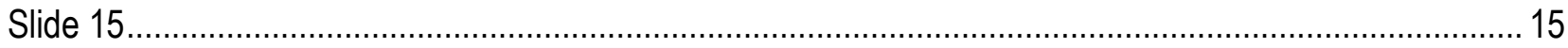

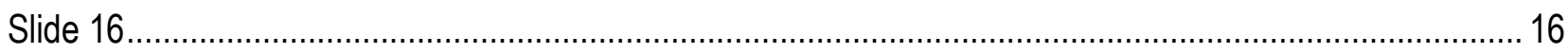

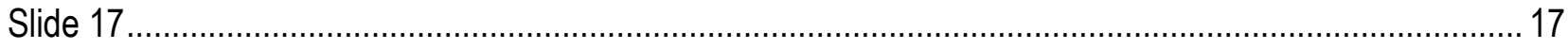

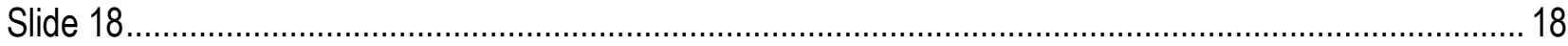

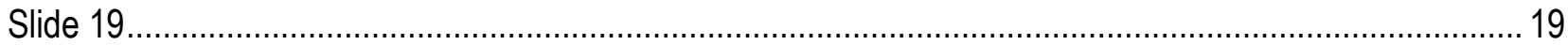

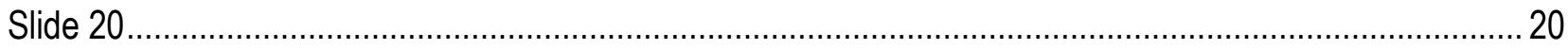

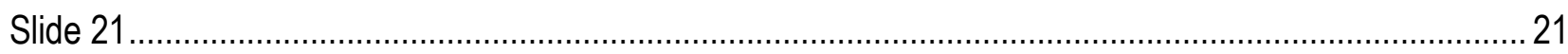

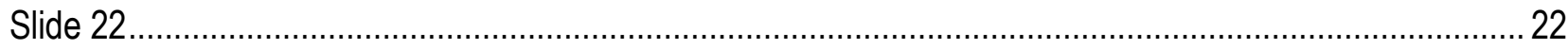

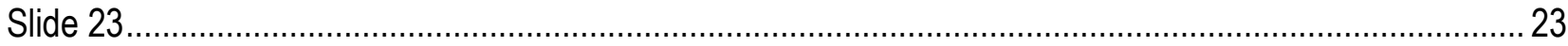

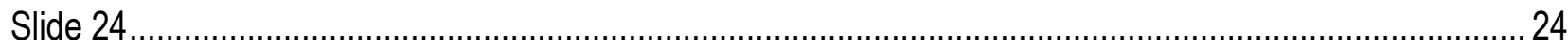

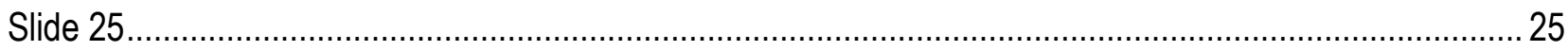

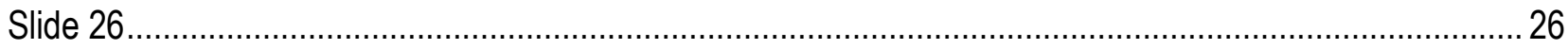

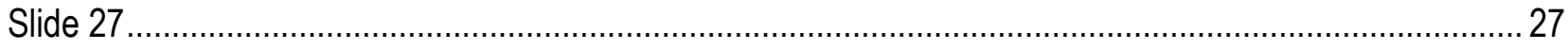

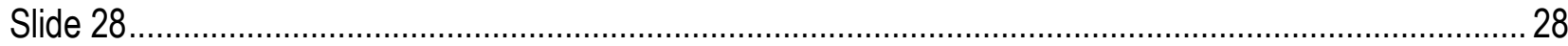

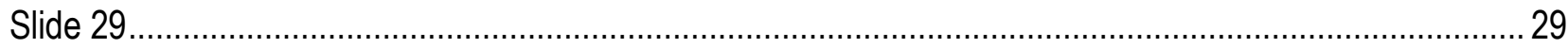

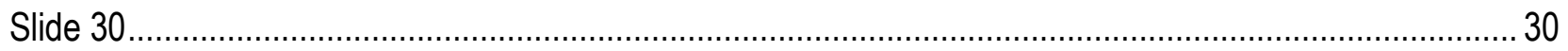

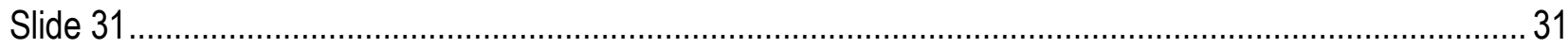

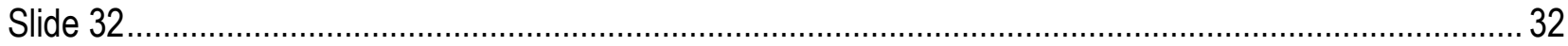

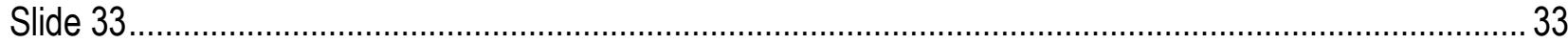

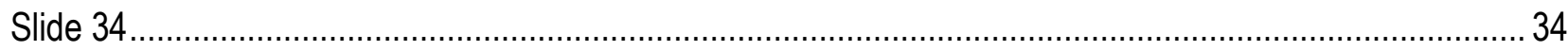

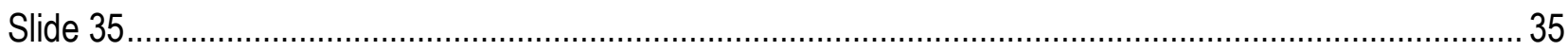

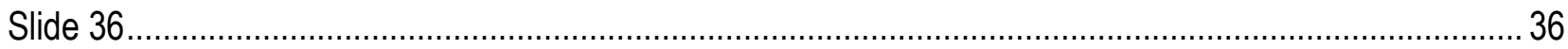

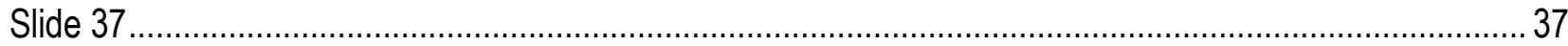

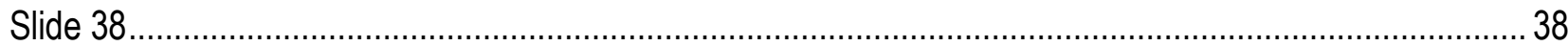

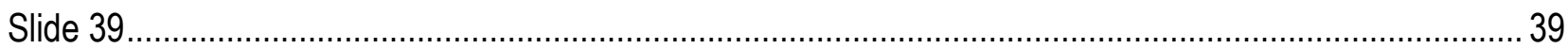

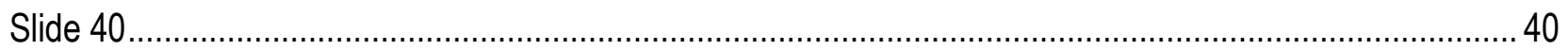

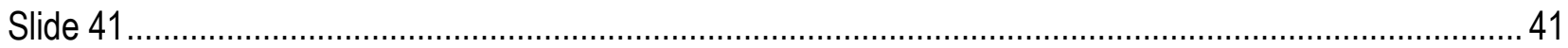

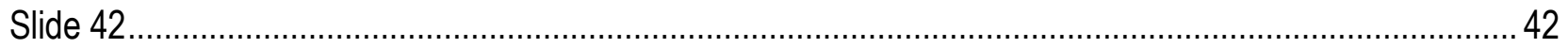

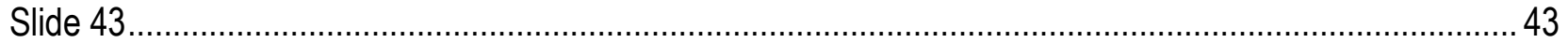




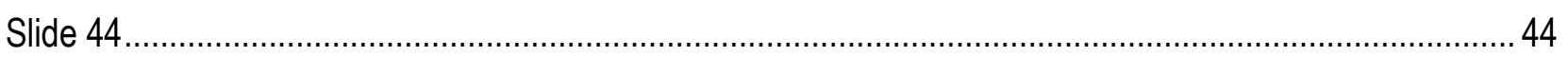

Slide 45

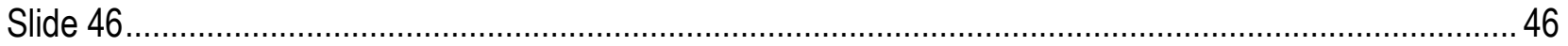

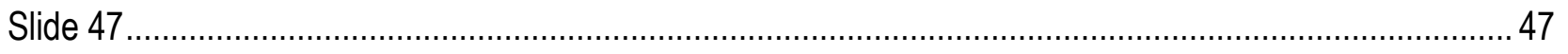

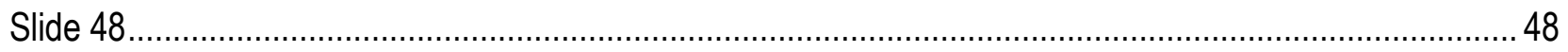

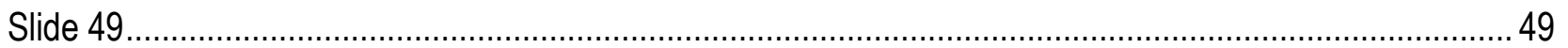

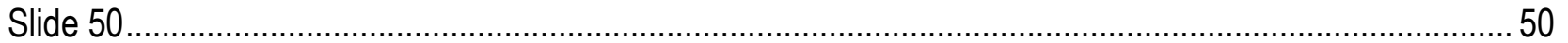

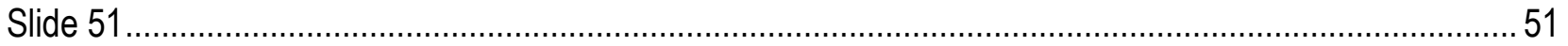

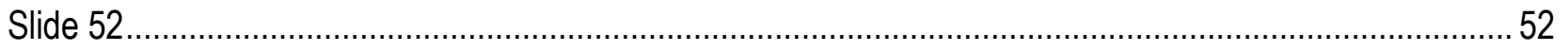

Slide 53

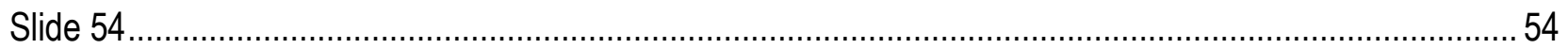

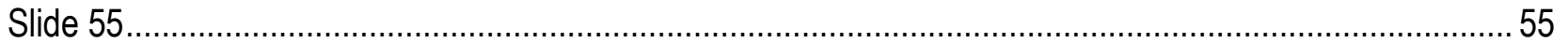

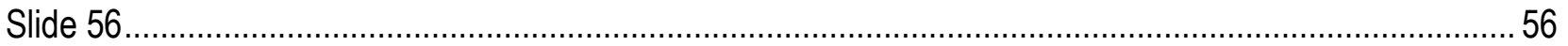

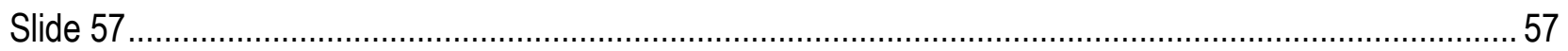


Slide 1

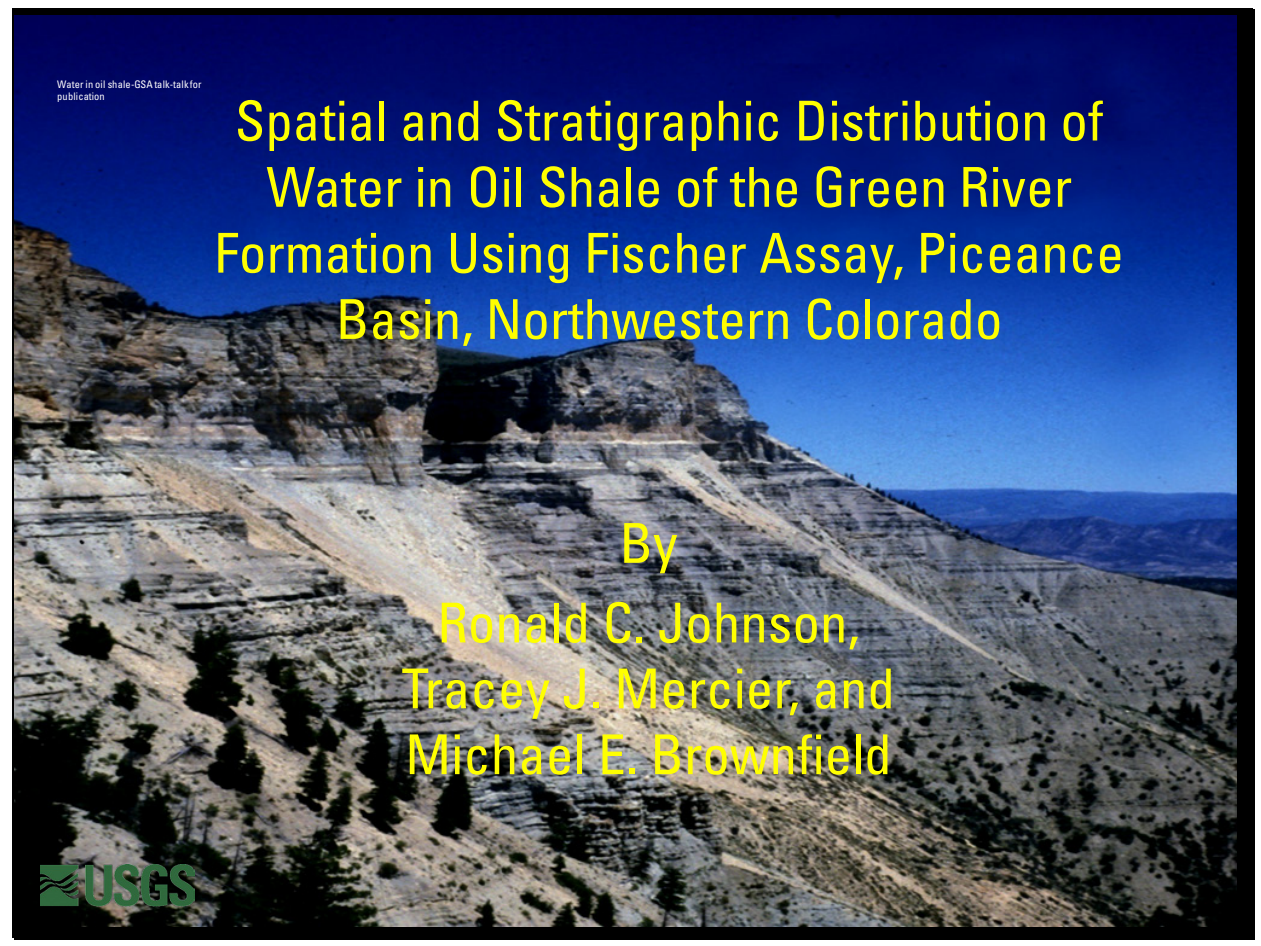


Slide 2

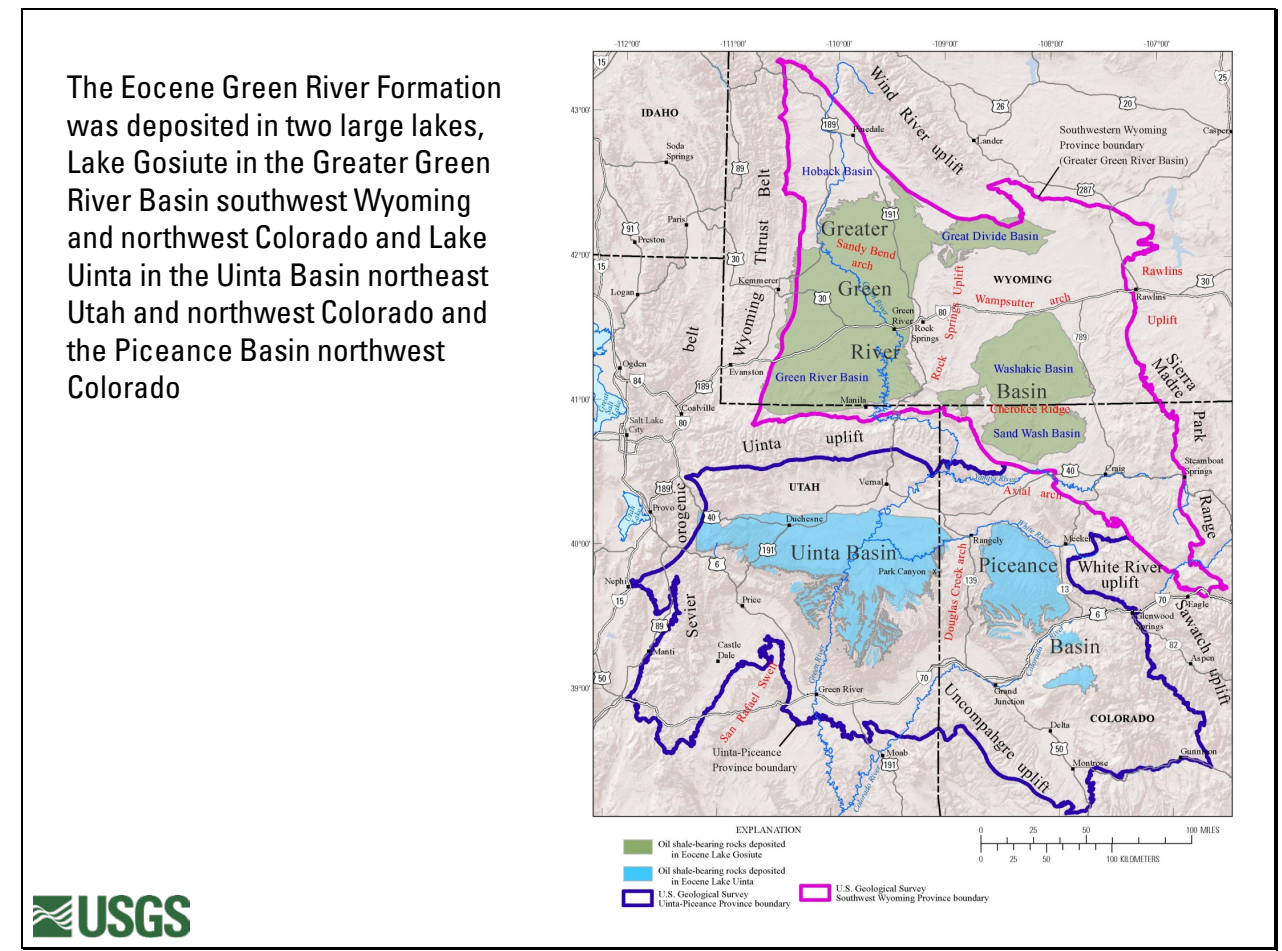


Slide 3

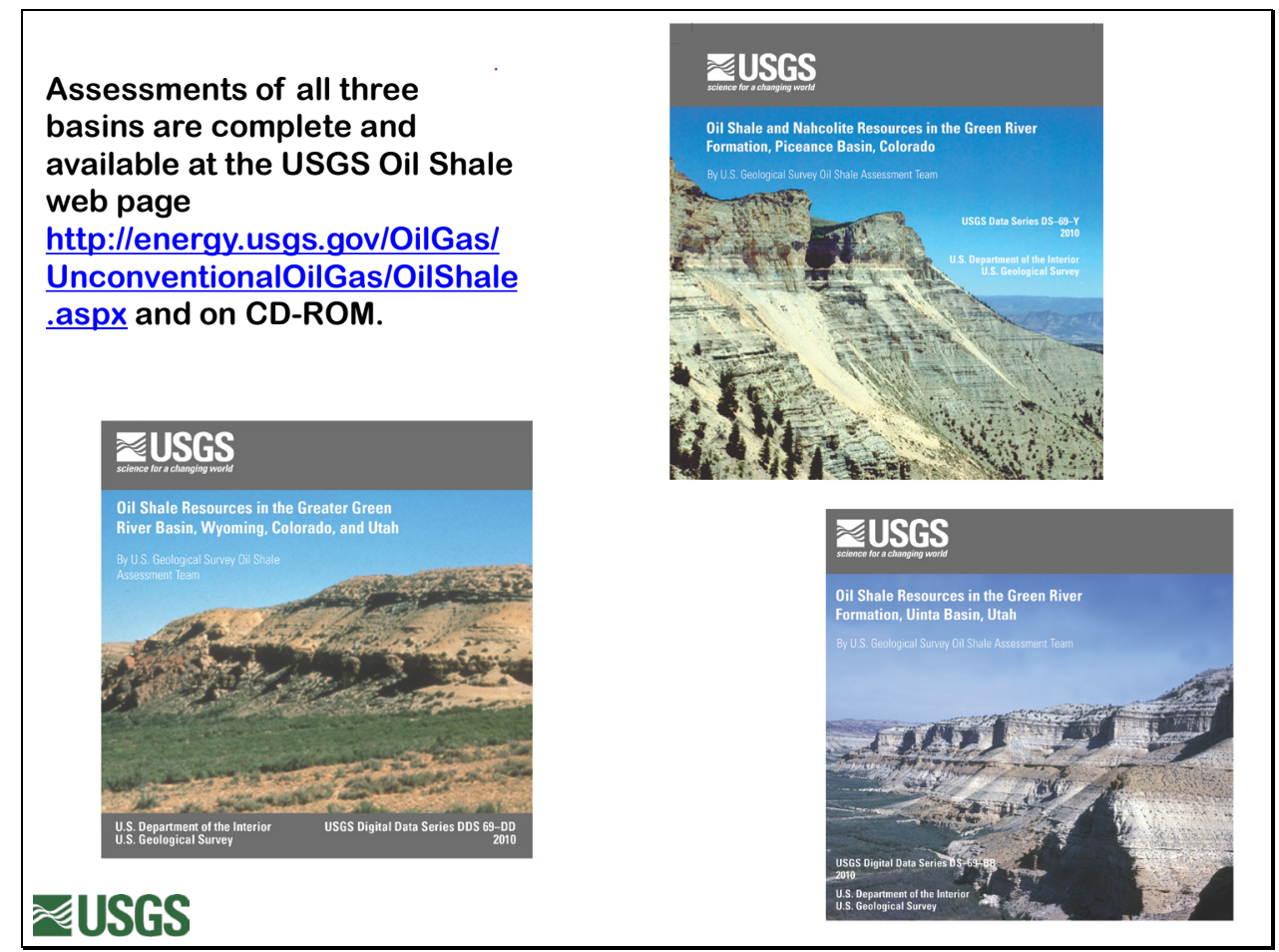

The U.S Geological Survey has now completed and published assessments of in-place oil in the Eocene Green River Formation in the Piceance Basin of western Colorado, the Uinta Basin of eastern Utah and western Colorado, and the Greater Green River Basin of southwest Wyoming. 
Slide 4

Piceance Basin: 1,335 square miles (3,458 square kilometers). In-place resource: 1.52 trillion barrels (Johnson and others, 2010a).

Uinta Basin: 3,834 square miles (9,930 square kilometers). In-place resource: 1.32 trillion barrels (Johnson and others, 2010b).

Greater Green River Basin: 5,500 square miles $(14,244$ square kilometers). In-place resource: 1.44 trillion barrels (Johnson and others, 2011).

The Piceance Basin has the smallest area and largest resource.

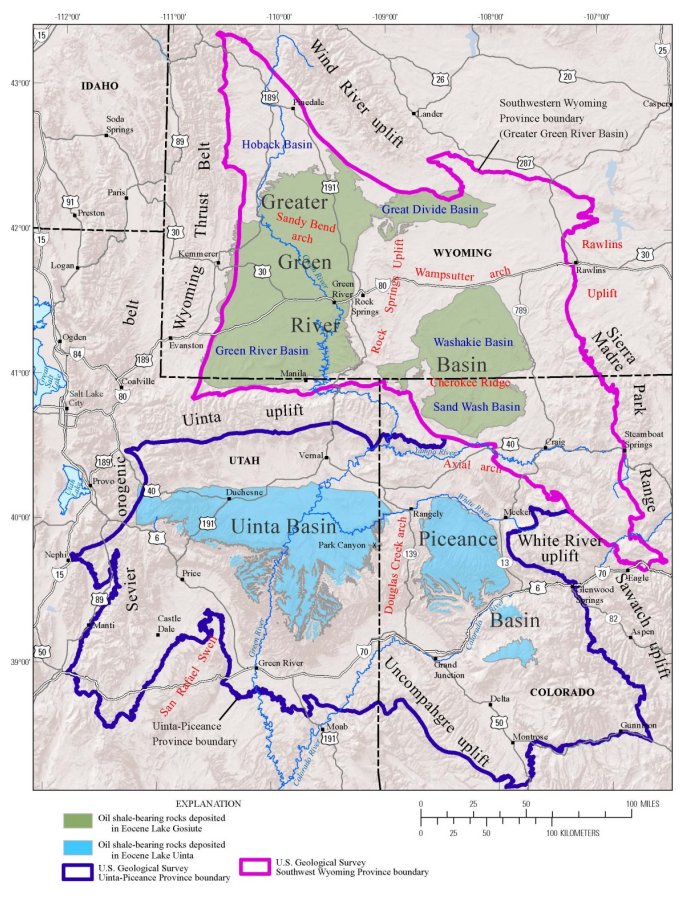


Slide 5

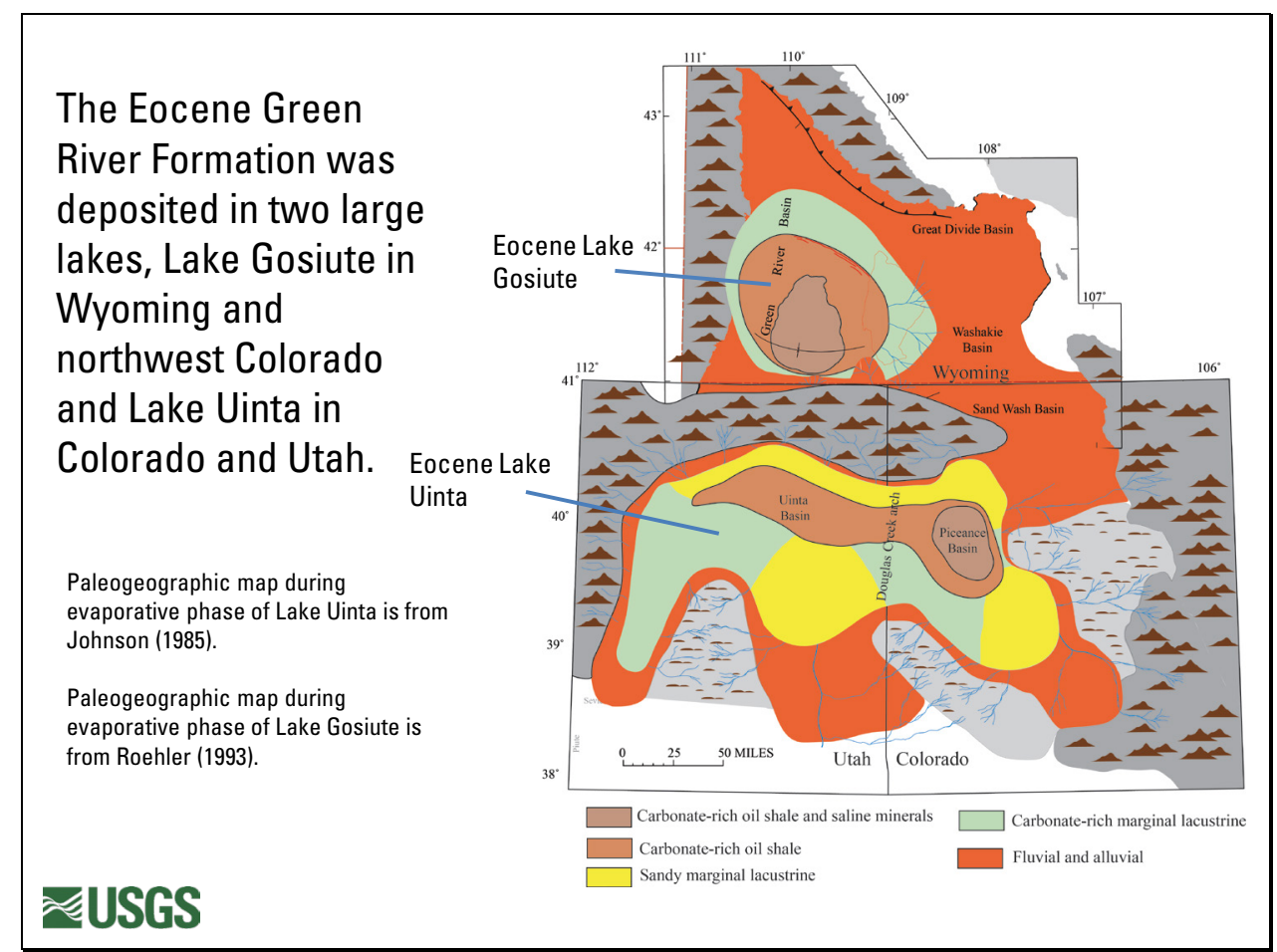

The Eocene Green River Formation was deposited in two large lakes: (1) Lake Gosiute in the Greater Green River Basin, and (2) Lake Uinta in the Uinta and Piceance Basins. Lake Uinta extended across the Douglas Creek arch throughout most, if not all, of its history. 
Slide 6

\section{All data used for each of the three assessments were put into a single Access table}

- The ability to create custom forms in Access was a crucial element in the assessment methodology as it allowed staff to write Visual Basic scripts and Structured Query Language (SQL) statements to filter subsets of the data and perform the necessary calculations using Access form controls.

- After resources were calculated for each core hole, the resultant Access tables were linked seamlessly with ESRI's ArcGIS software to model, extrapolate, and quantify the data spatially.

- The end product is a database of tables (spreadsheets), forms to view the data and a series of GIS maps quantifying the results of those calculations. 
Slide 7

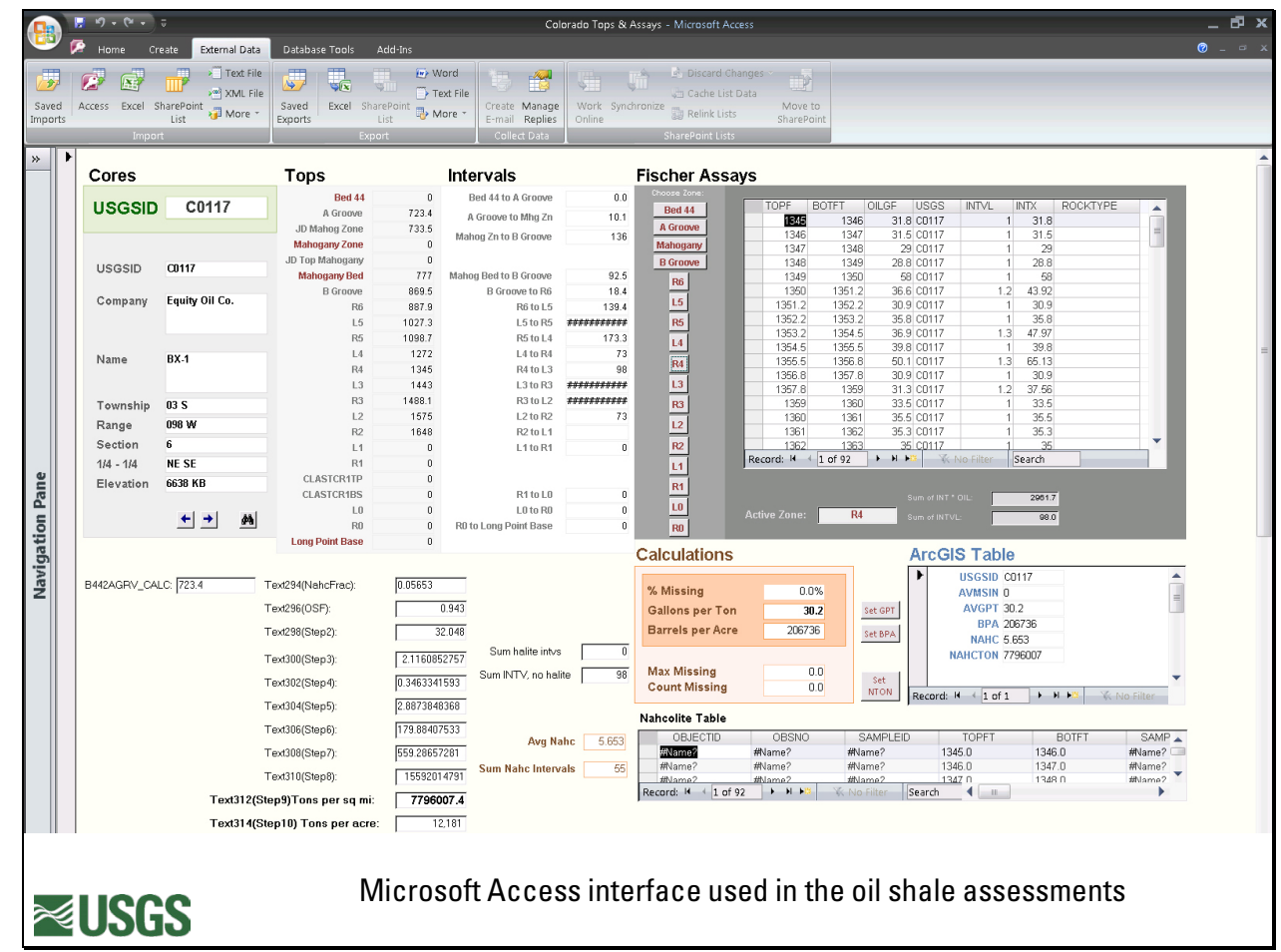

The published database with the in-place assessment of oil shale resources in the Piceance Basin is used here to generate maps showing variations in water content. 
Slide 8

\section{Data included in Access table for Piceance Basin oil shales}

- Tops, 1,049 records

- Fischer Assay analyses, 321,410 records

- Nahcolite measurements, 37,716

- Resultant ArcGIS table to store calculations, 2,615 records (points for all 3 states) 
Slide 9

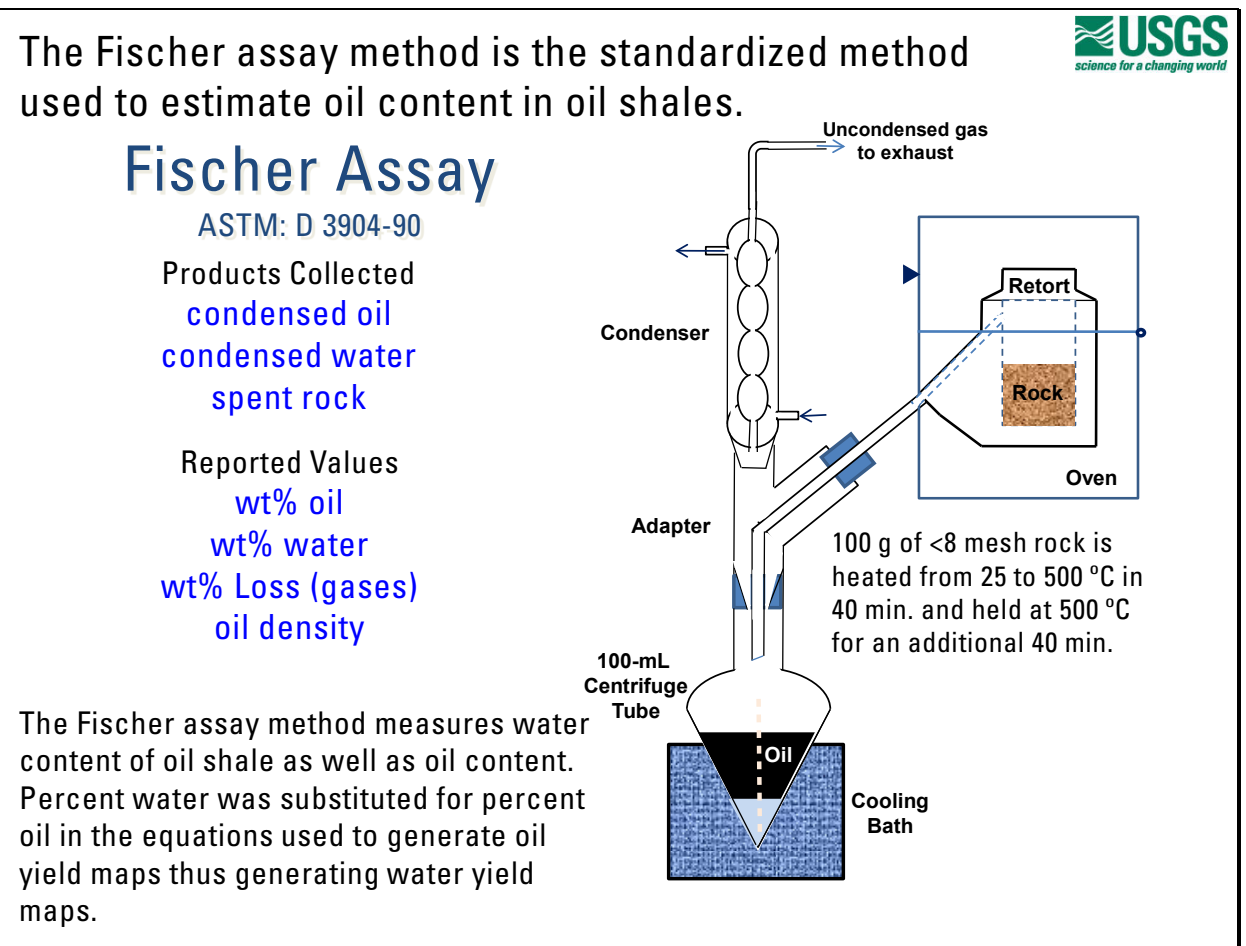


Slide 10

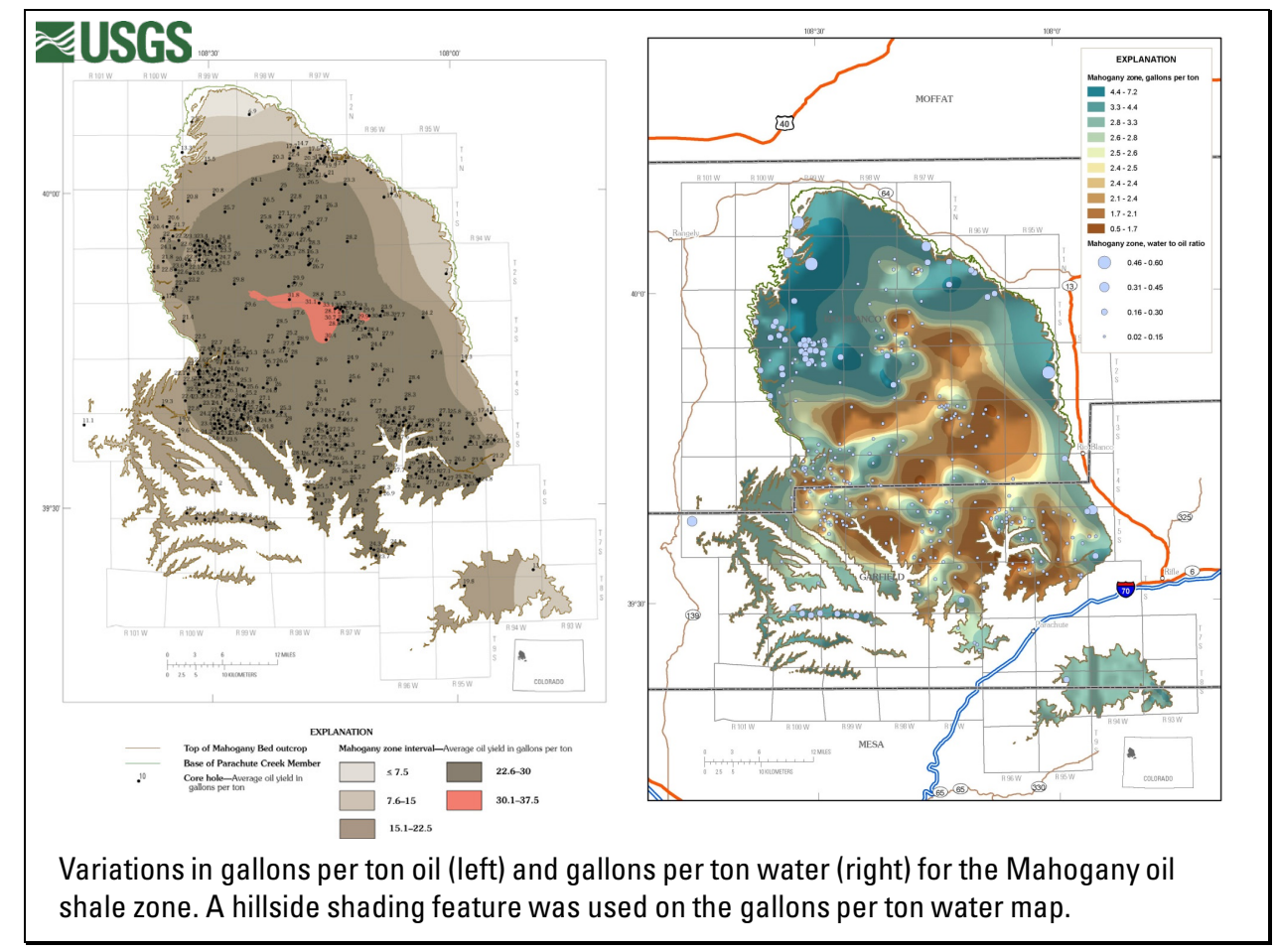


Slide 11

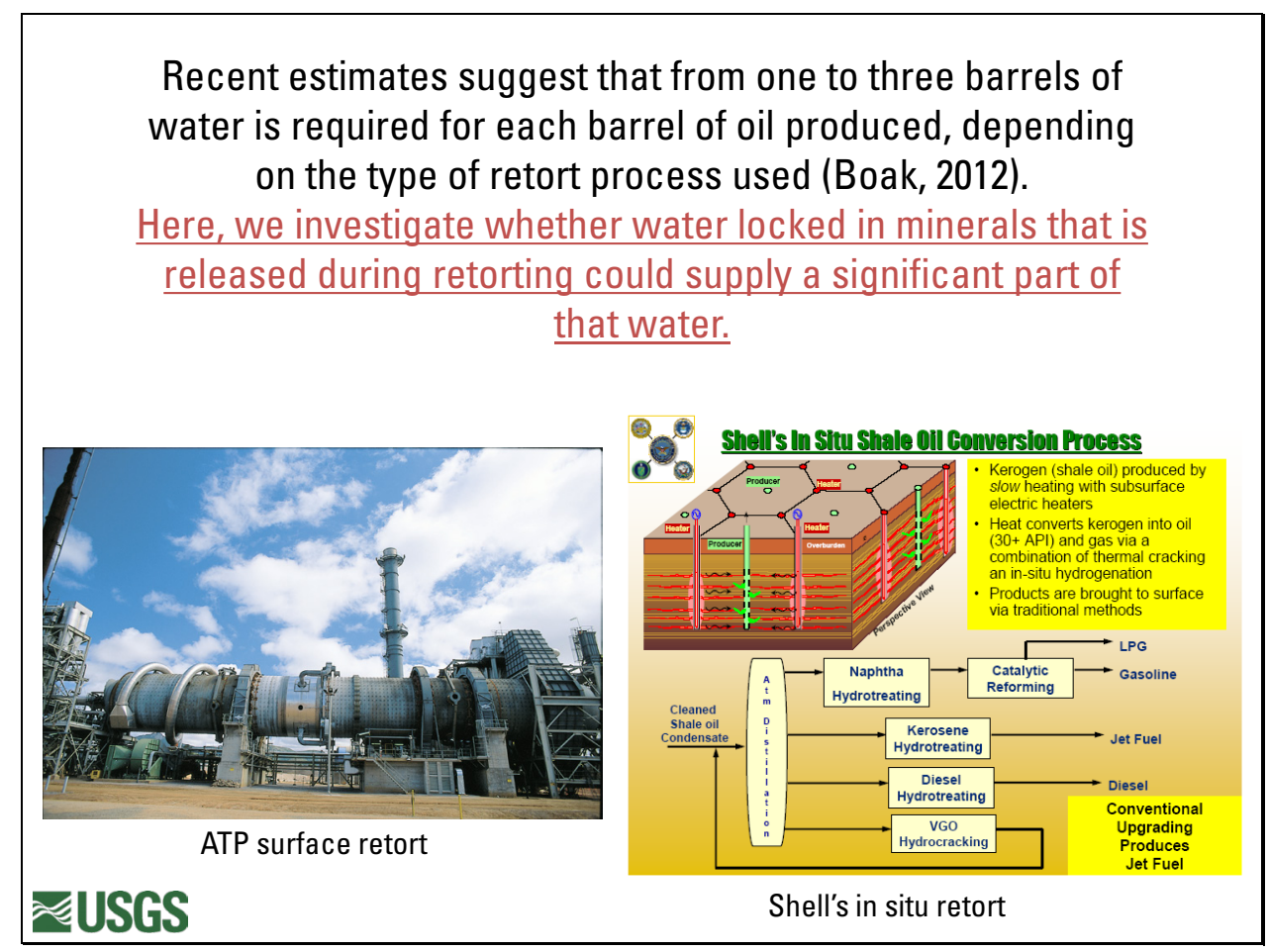


Slide 12

The Piceance Basin is a high semiarid plateau with limited water resources. Water in the major rivers in the areas is largely allocated for states, municipalities, and irrigation.

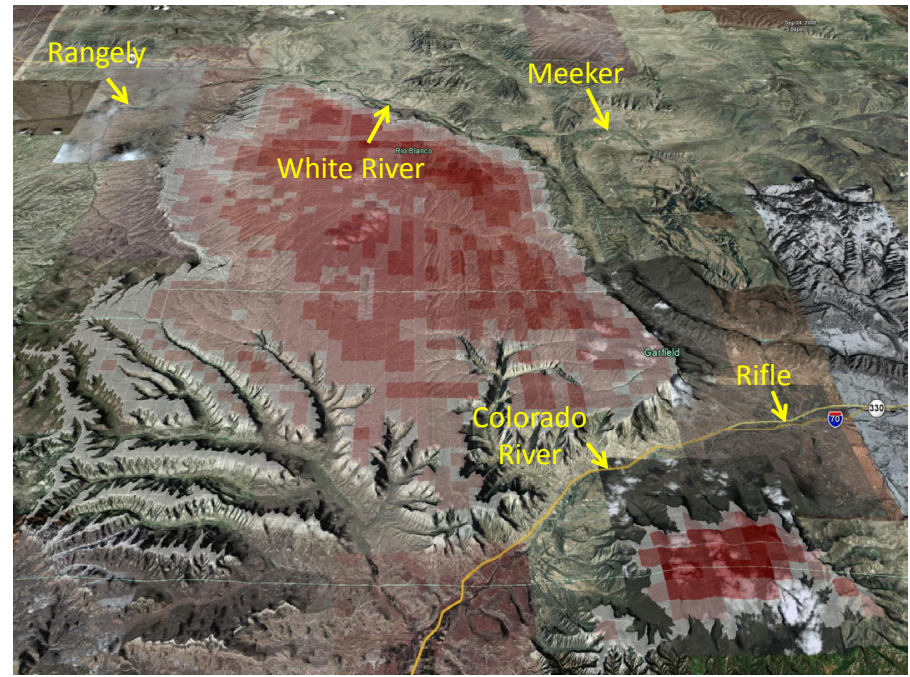

Oblique photograph of the oil shale deposits of the Piceance Basin with a overburden map showing cubic miles of surficial deposits (in red) per square mile; the darker the shade, the thicker the overburden deposits. 
Slide 13

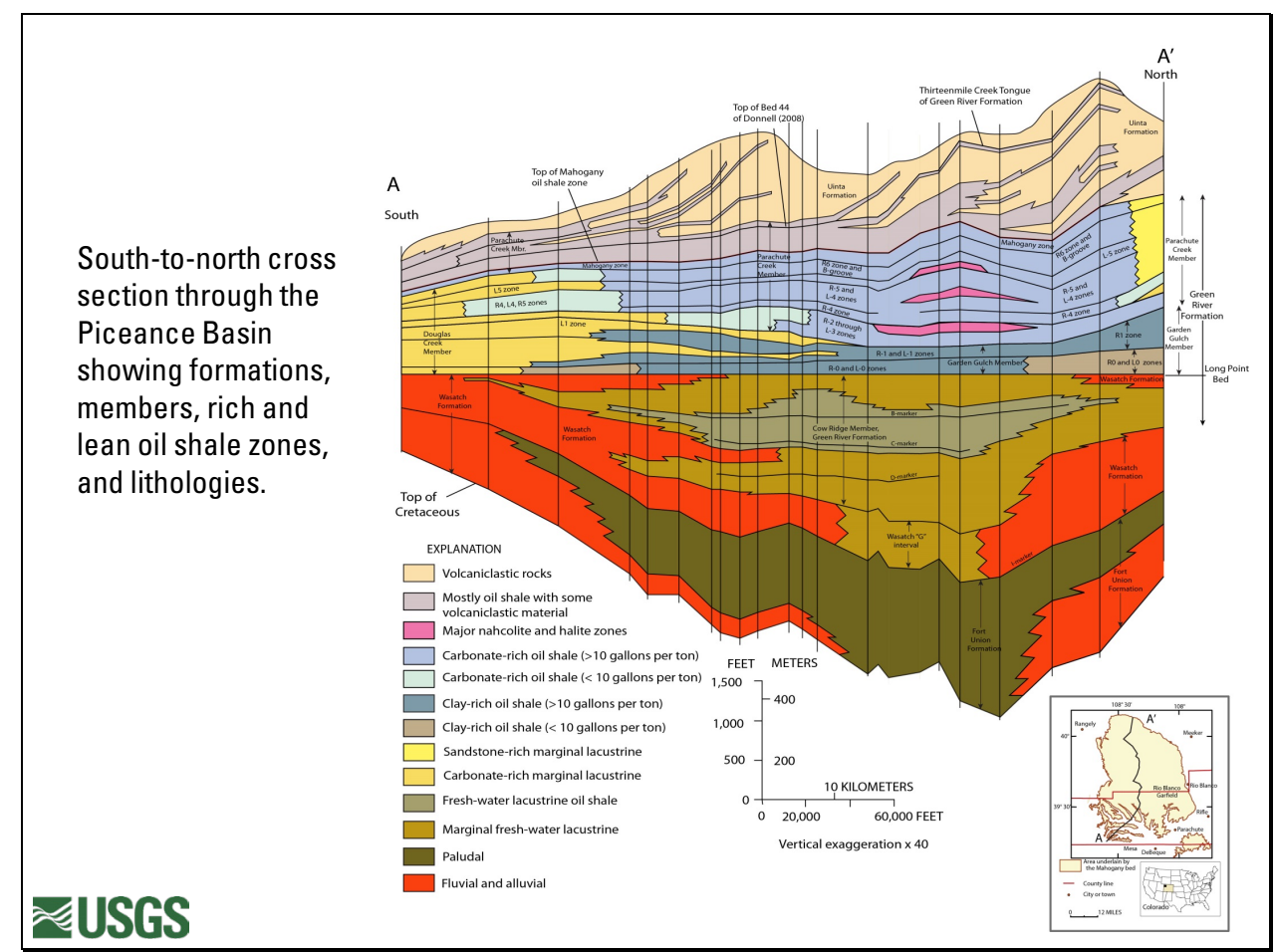

This south-to-north general cross section of the Piceance Basin shows: (1) members of the Green River Formation, (2) the rich and lean zone stratigraphy defined by Cashion and Donnell (1972), and (3) environments of deposition. Major nahcolite and halite zones in the north-central part of the basin are shown. Note that the oil shale interval grades toward the basin margins into marginal lacustrine rock. Note also the infilling of Lake Uinta in the Piceance Basin by volcaniclastic sediments from the north after deposition of the Mahogany oil shale zone. 
Slide 14

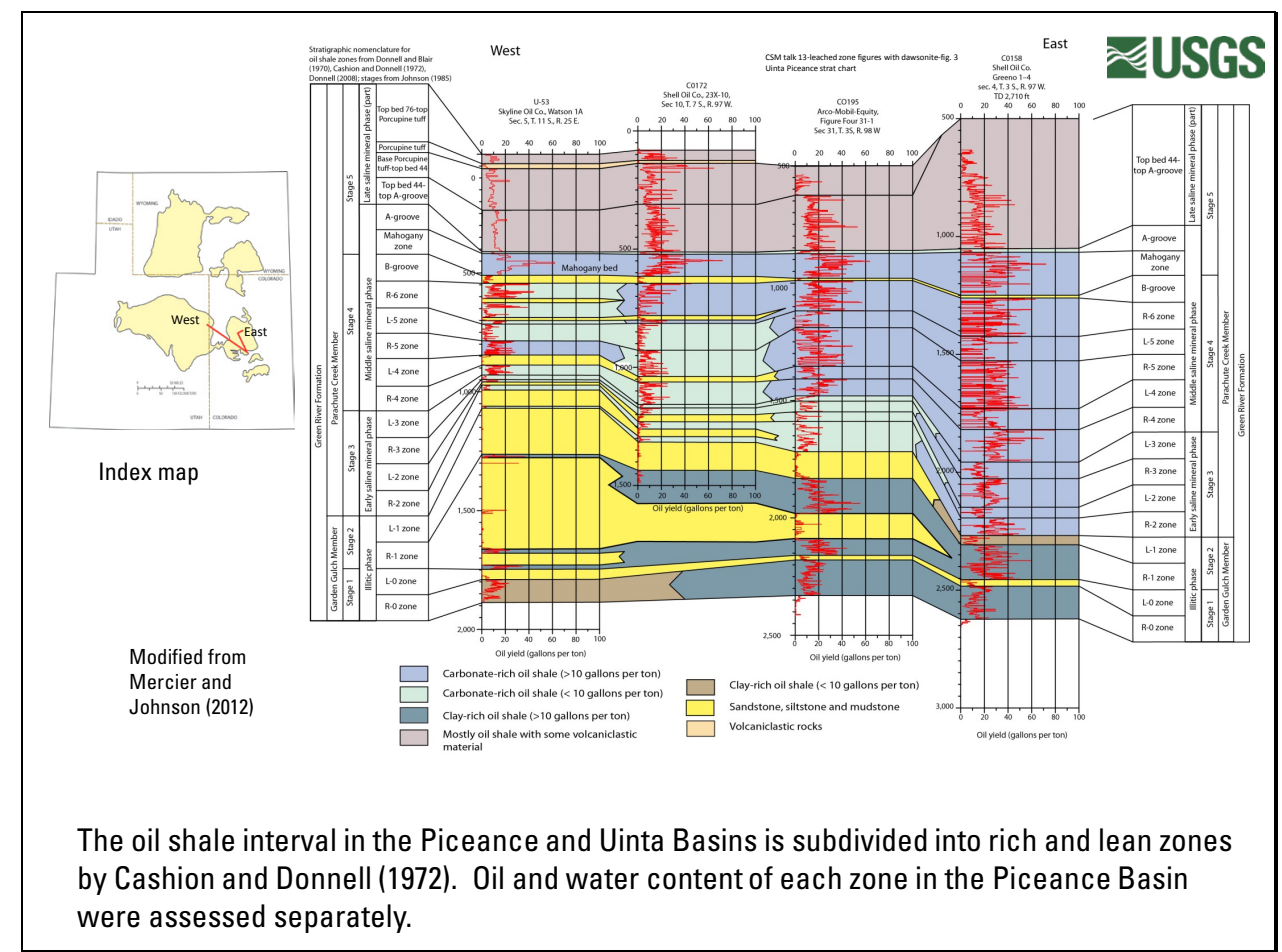

Cashion and Donnell (1972) were the first to subdivide the oil shale interval into roughly time stratigraphic rich and lean zones that represent alternating periods of high and low organic productivity and preservation in Lake Uinta. 
Slide 15

\section{Maps generated}

- Gallons of water per ton of oil shale

- Gallons of water per acre ${ }^{1}$

- Gallons per ton is a measure of average water content

- Gallons per acre is a measure of tota/water in place

1 Oil was estimated in barrels of oil per acre. However, water is not measured in barrels, and thus gallons of water per acre is used here.

₹USGS

The gallons per ton water and gallons per acre water maps presented here were generated from the same database using the same formulas as the gallons per ton oil and barrels per acre oil maps presented in the assessment of in-place oil shale resources (Johnson and others, 2010a). Gallons of water per acre was used instead of barrels of water per acre, because water content is generally not measured in barrels. 
Slide 16

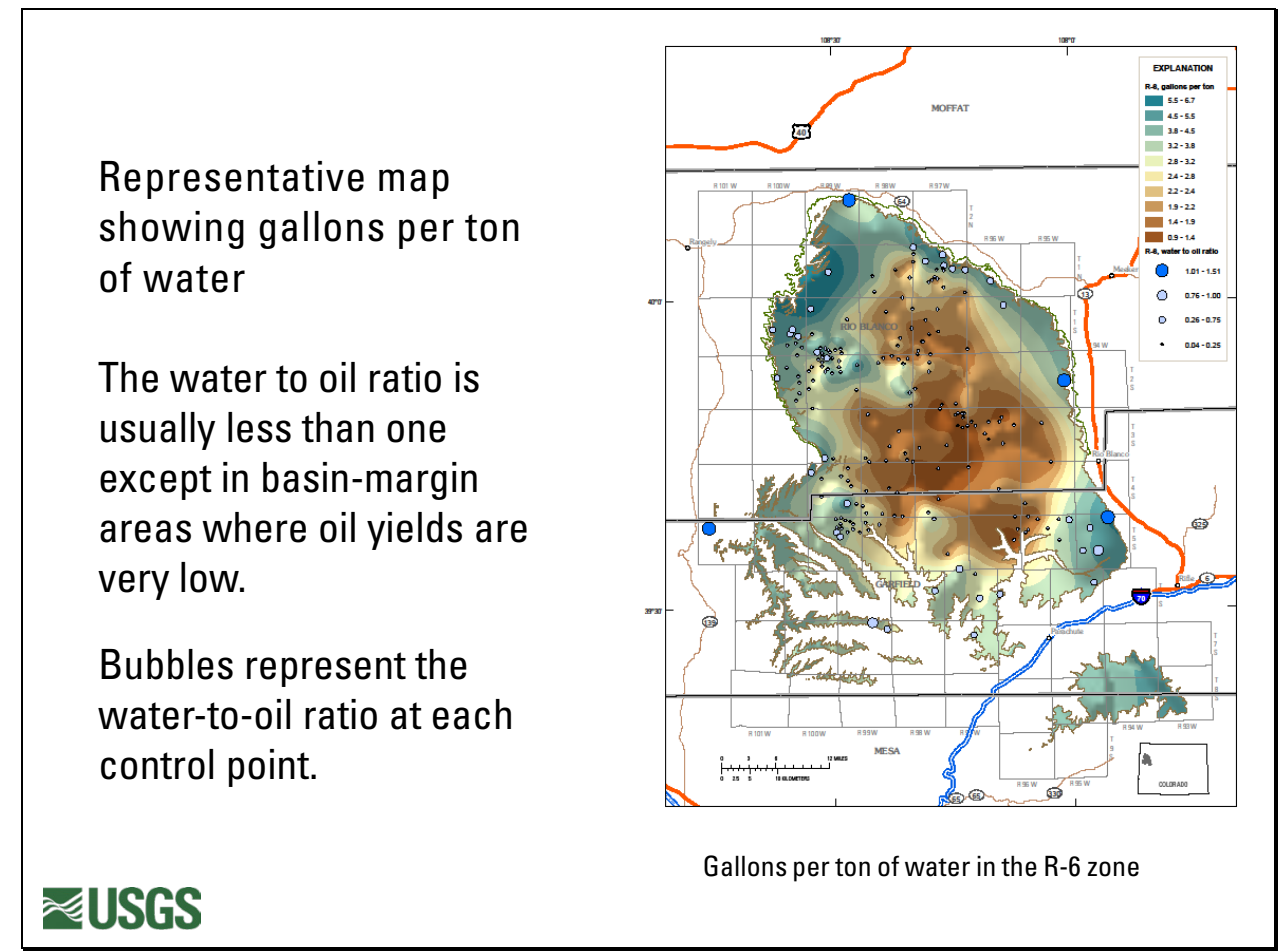

The in-place water maps presented here resemble the in-place oil maps generated by Johnson and others (2010a) except a hillside shading feature is used on the in-place water maps to enhance the visualization of variations in water content. 
Slide 17

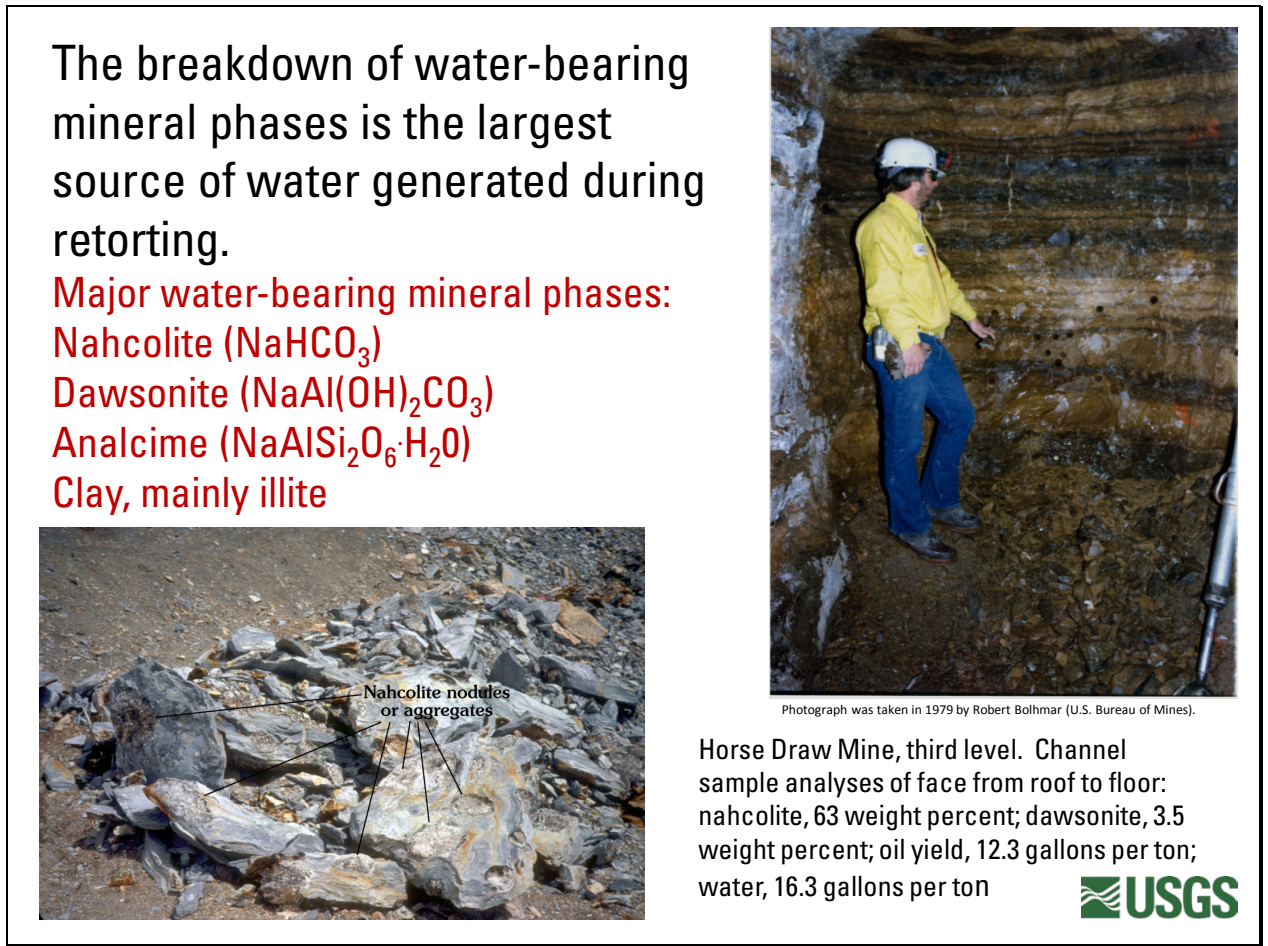

Most of the water generated during retorting probably comes from water-bearing mineral phases, such as nahcolite, dawsonite, analcime, and clay. All of these minerals lose most if not all of their water at retort temperatures. 
Slide 18

- Nahcolite and dawsonite are present in the richest part of the oil shale deposit in the north-central part of the basin.

- Nahcolite decomposes to natrite $\left(\mathrm{Na}_{2} \mathrm{CO}_{3}\right)$ or soda ash, carbon dioxide, and water at temperatures near $100^{\circ} \mathrm{C}$ during the recovery processes.

- Dawsonite decomposes to soda ash, $\mathrm{Al}_{2} \mathrm{O}_{3}$, water, and carbon dioxide at temperatures of 200 to $370^{\circ} \mathrm{C}$.

- In addition, nahcolite is considered a leasable mineral and, thus, must not be destroyed during processes used to recover oil from oil shale.

₹USGS 
Slide 19

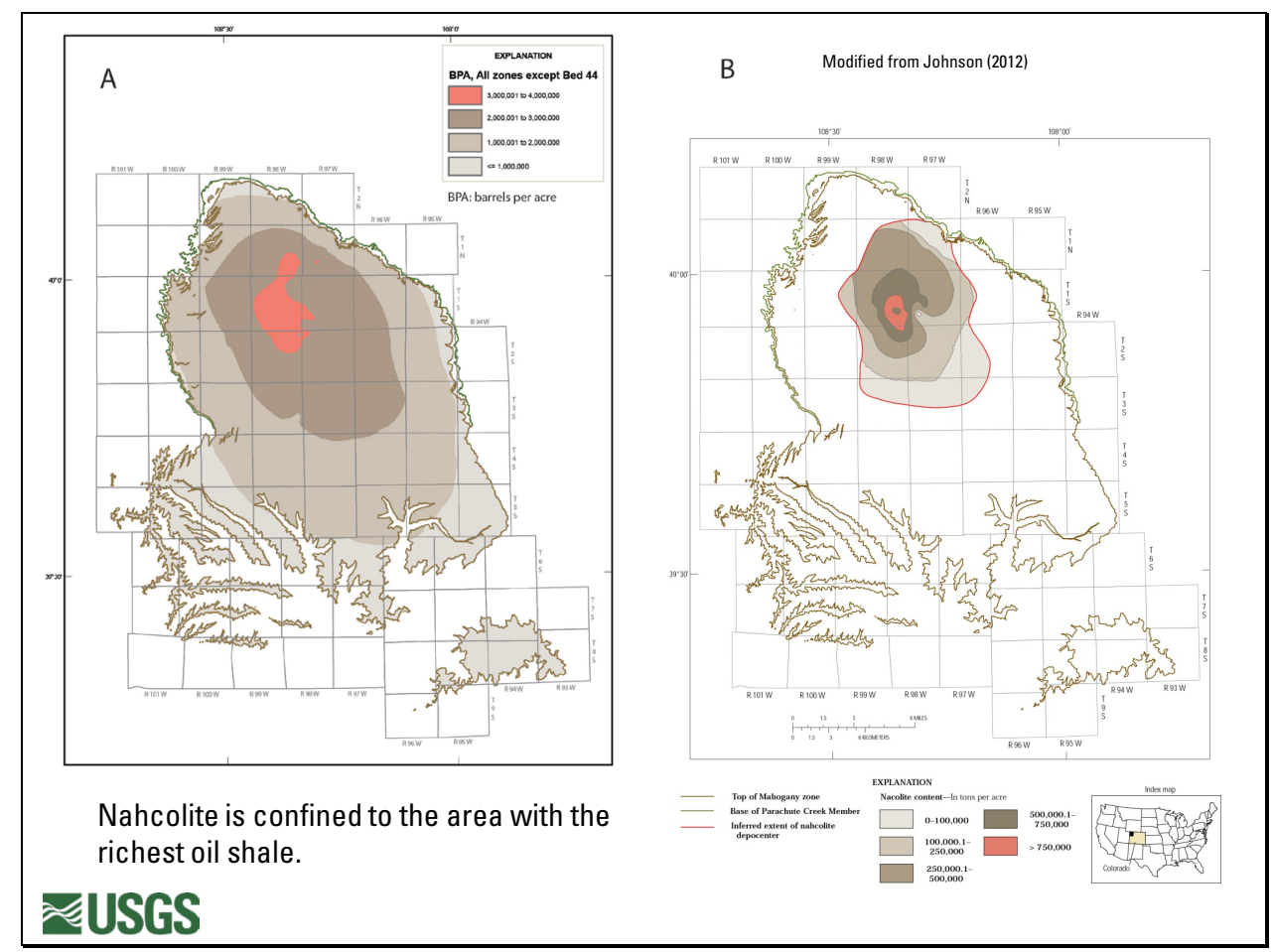

The map on the left shows total amount of oil in place in all seventeen oil shale zones in the Piceance Basin. The area containing nahcolite (outlined by brown line) is shown on the right. The area with the most oil in place is generally the same as the area containing nahcolite, thus extracting oil from the richest oil shale interval in the basin will also necessitate the extraction or preservation of nahcolite. 
Slide 20

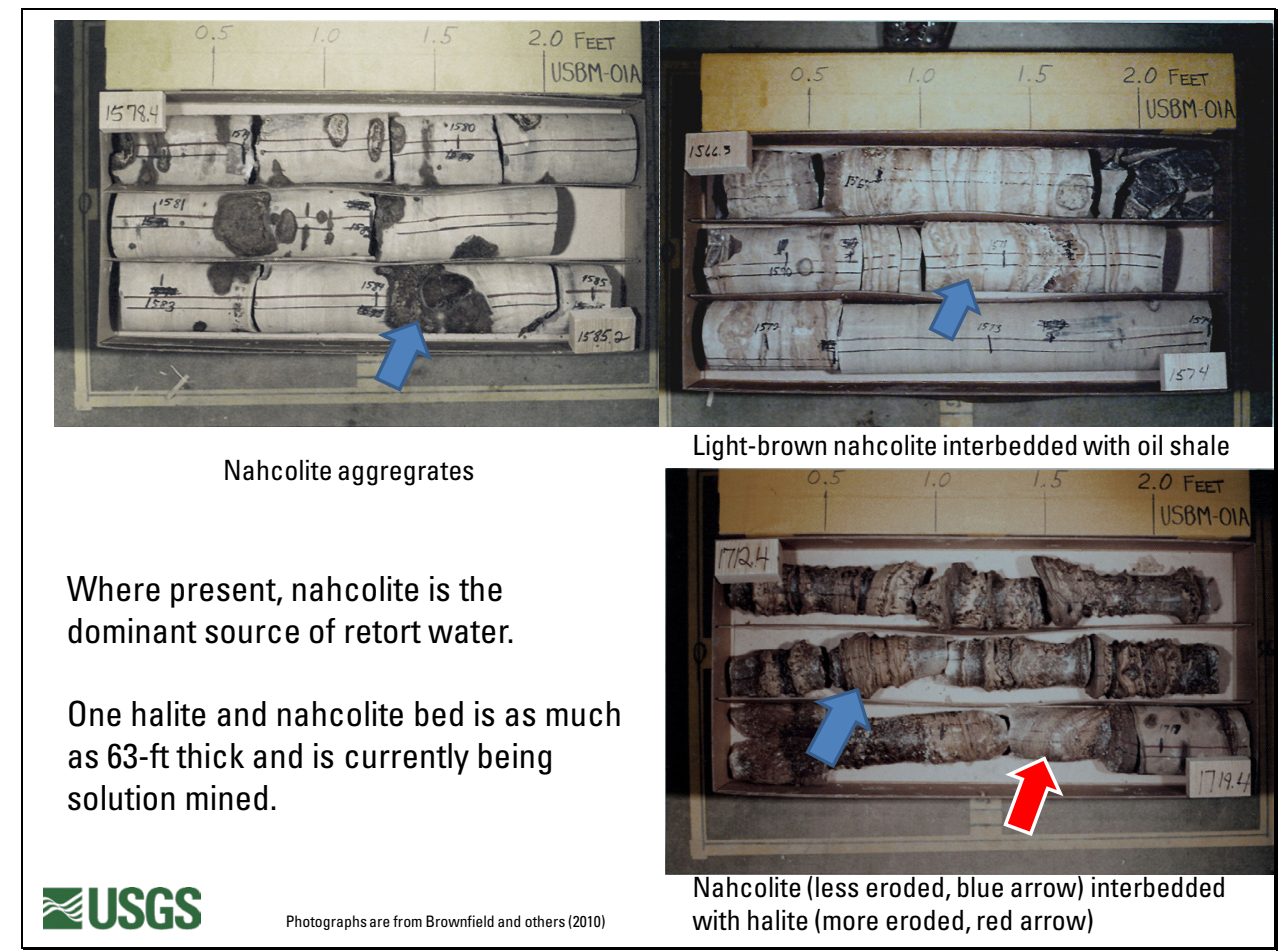

Nahcolite in the Piceance Basin occurs as: (1) nonbedded crystalline aggregates, (2) laterally continuous units of fine-grained crystals dissemintated in oil shale,( 3) brown crystalline beds, and (4) white coarse-grained beds (Dyni, 1974). Some of these types of nahcolite occurrences are shown here. 
Slide 21

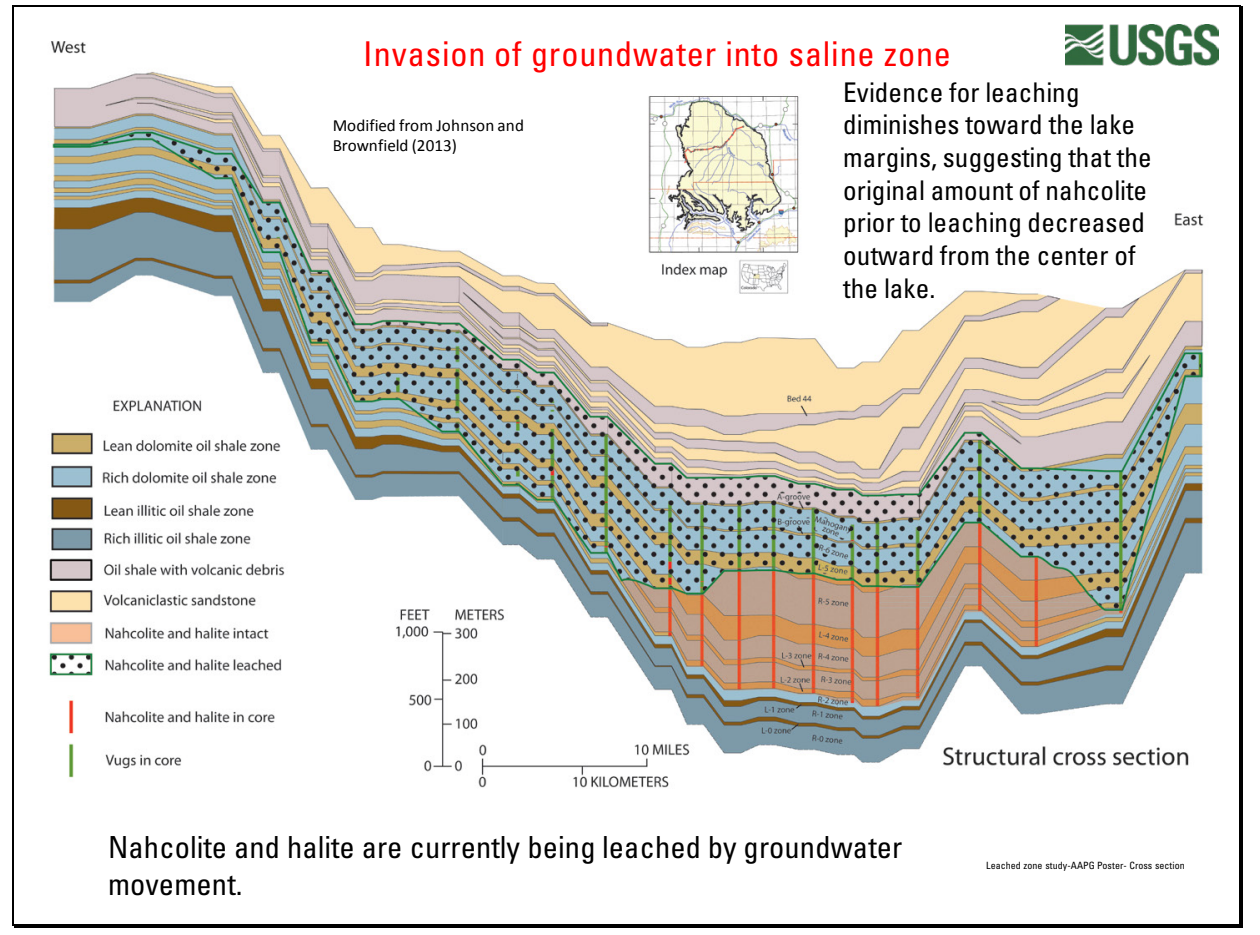

East-west structural cross section showing variations in elevation of the rich and lean oil shale zones in the Piceance Basin. Structural cross sections such as this are more useful to visualize groundwater movement than stratigraphic cross sections where the datum is a stratigraphic horizon. Note the extensive interval where nahcolite and halite have been leached. 
- “Dawsonite occurs as minute crystals 5 microns or less in size, disseminated throughout the oil shale matrix. Over short intervals, dawsonite may compose as much as 25 percent of the rock" (Beard and others, 1974, p. 103).

- Analcime is found in altered tuffs and disseminated in oil shale and other finegrained rocks.

ॠUSGS 
Slide 23

There appears to be no relation between kerogen content (indicated by oil yield) and water content, and kerogen does not appear to be a major source of water produced during retorting.

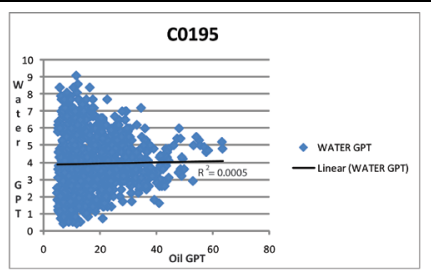

Colburn and others (1989) determined that dehydration of kerogen was only a minor source of water in Green River oil shales, contributing about $0.2 \mathrm{~g}$ of water per $100 \mathrm{~g}$ of oil shale.
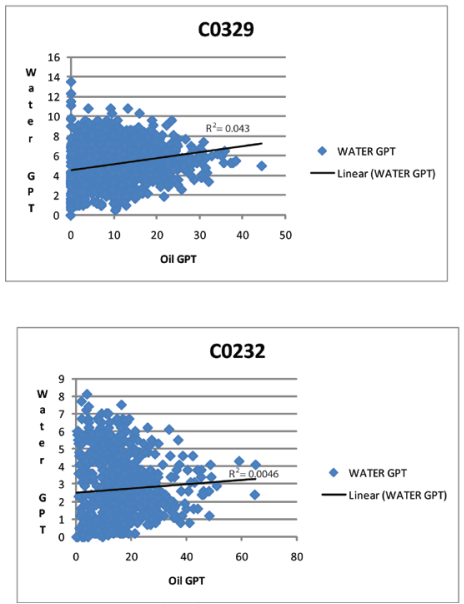
Slide 24

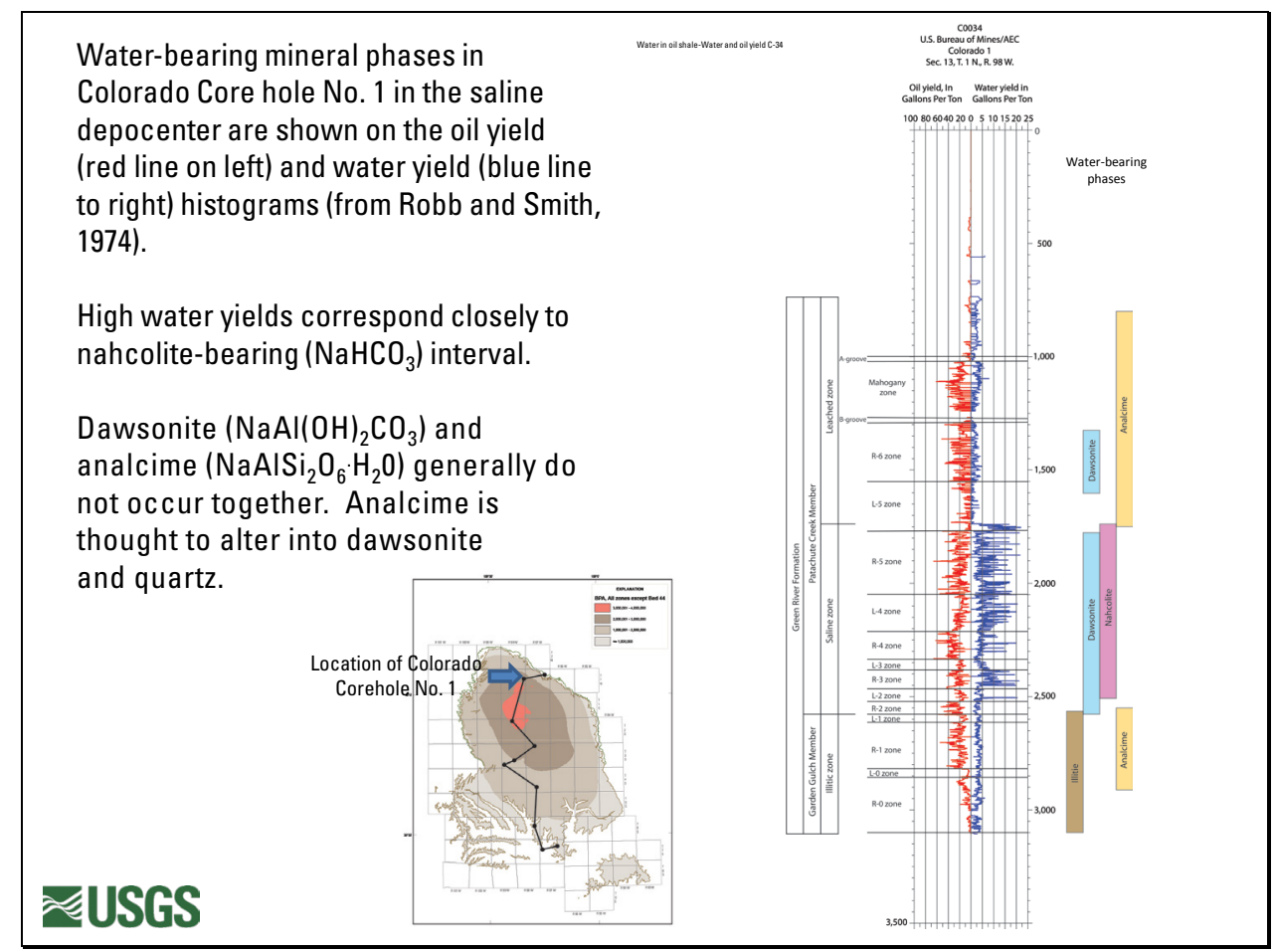


Slide 25

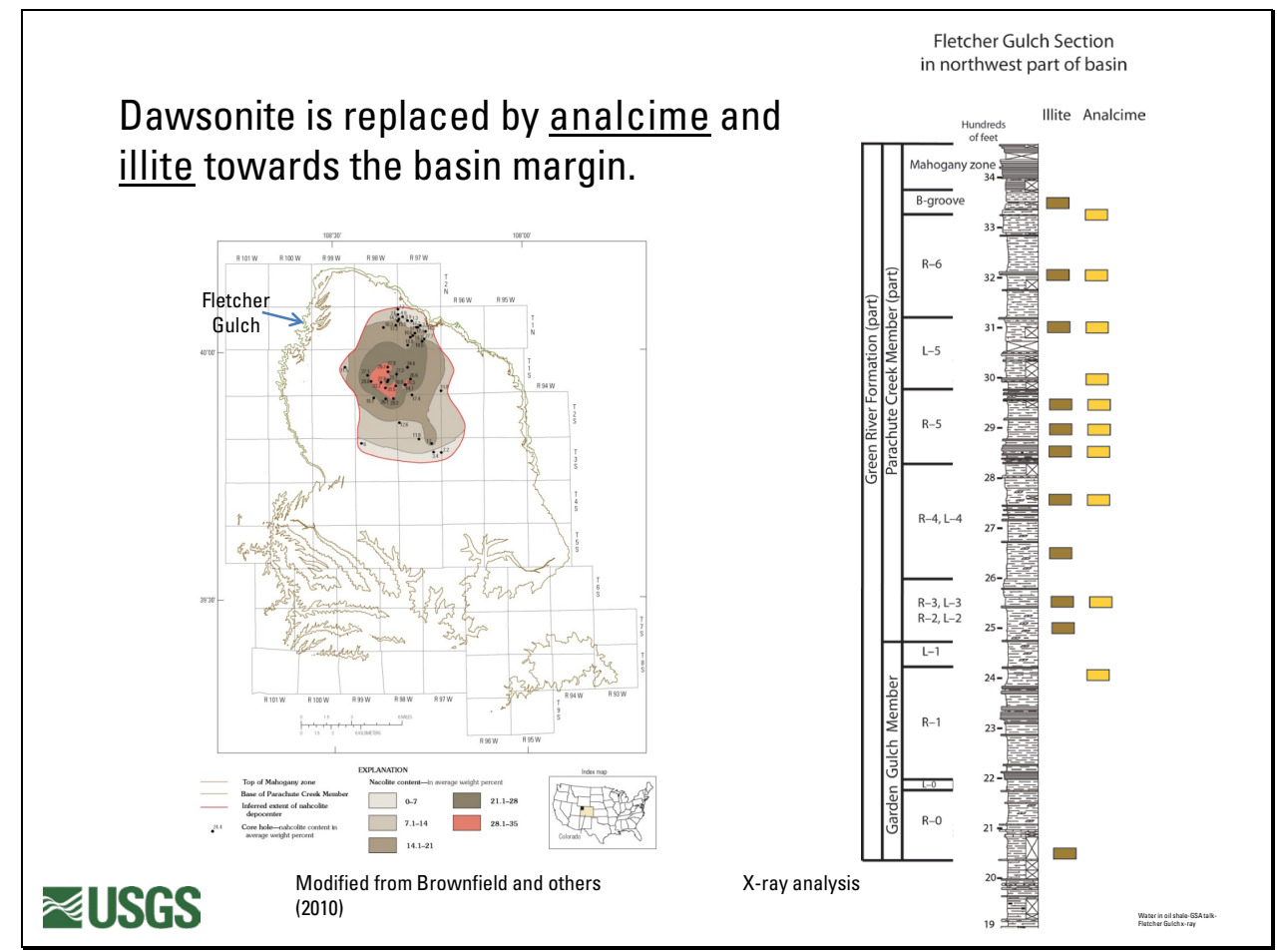

Illite and analcime appear to be the most common water-bearing mineral phases in marginal areas, but data are sparse. 
Slide 26

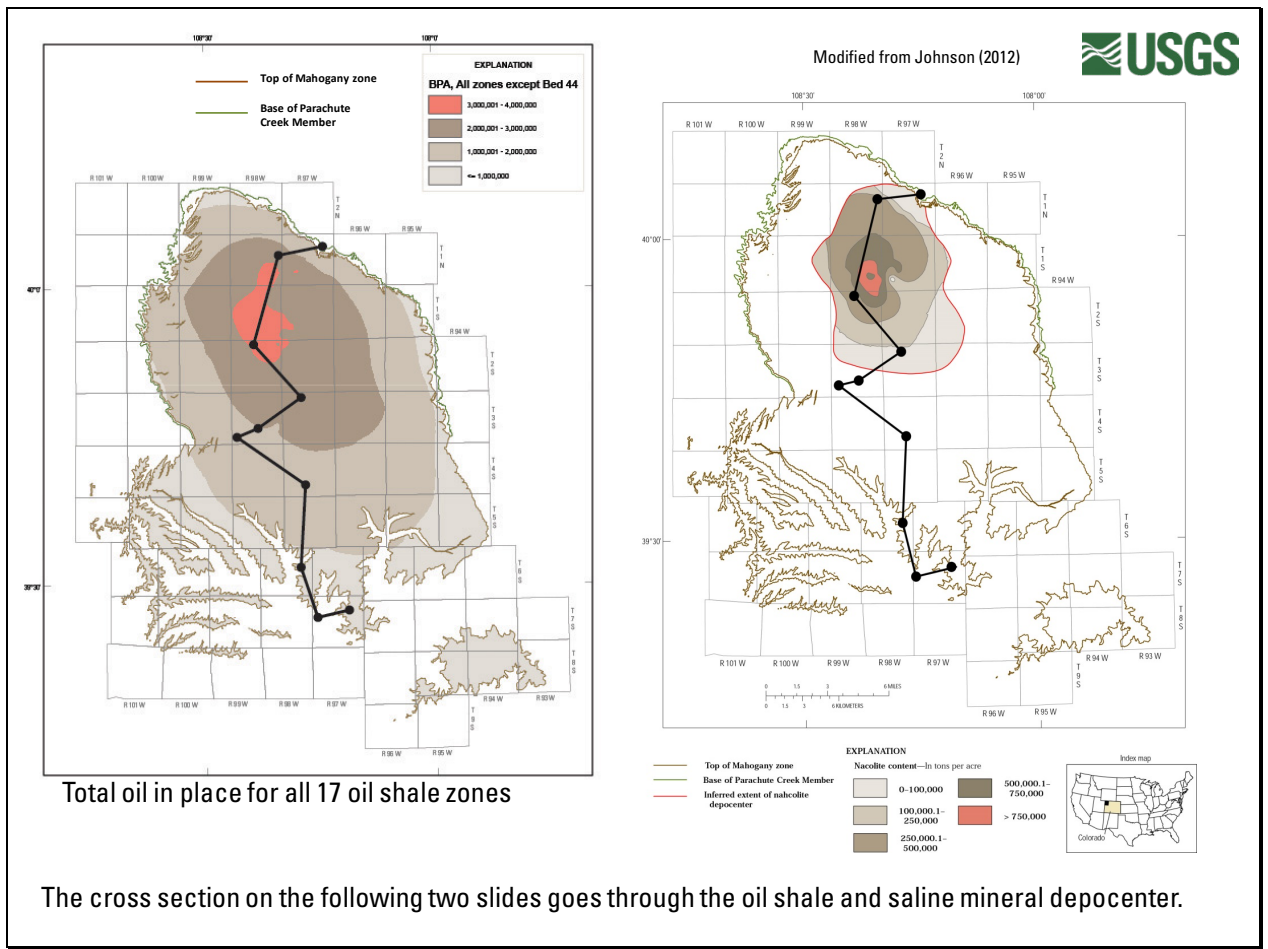

A south-to-north cross section through the Piceance Basin shows the distribution of waterbearing mineral phases in the Green River Formation. 
Slide 27

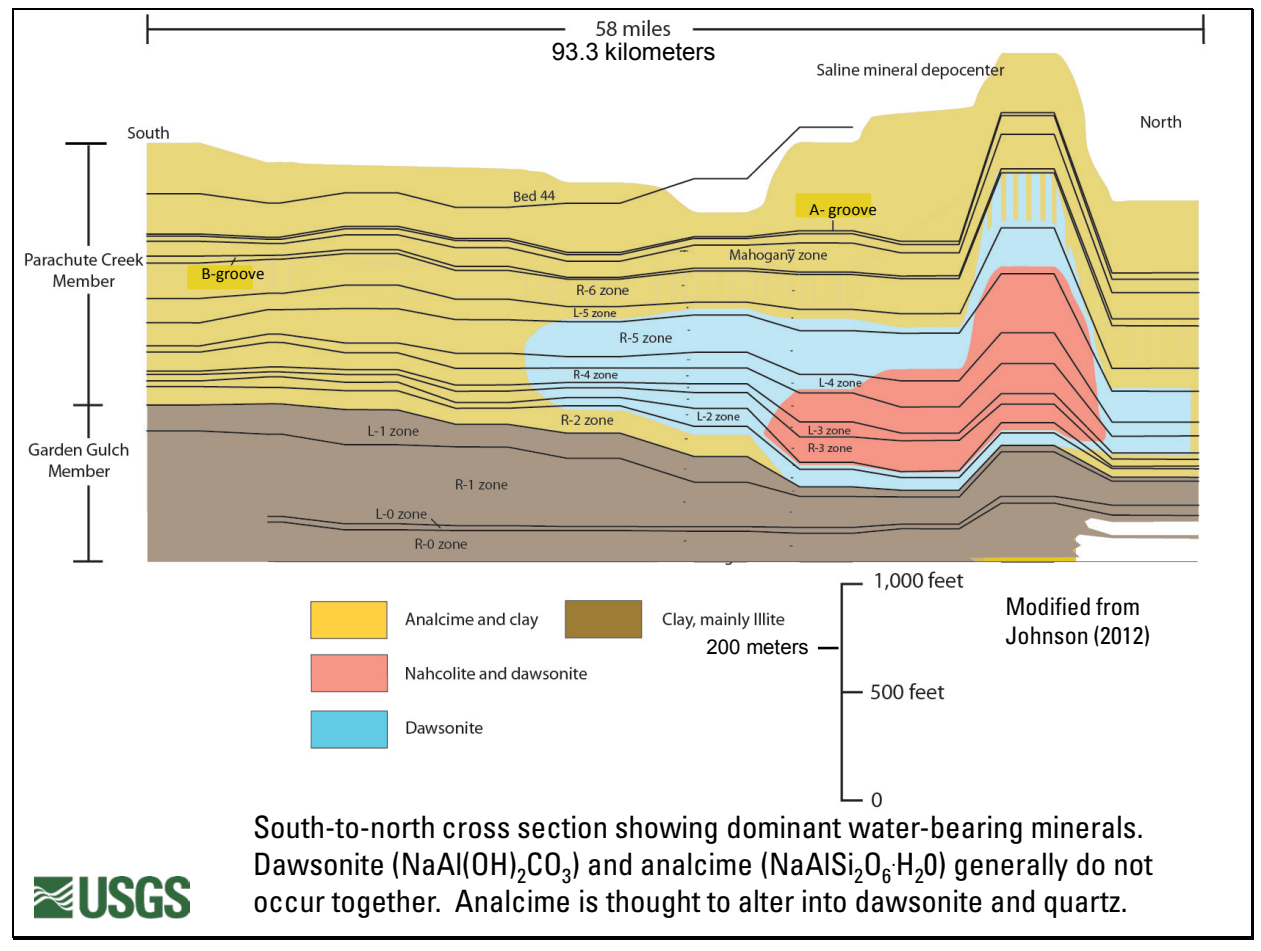

This south-to-north cross section shows members of the Green River Formation, rich and lean zones, and the distribution of water-bearing mineral phases. Nahcolite and dawsonite grade marginward into mainly illite and analcime. 
Slide 28

Maps showing variations in gallons per ton water and gallons per acre water were generated for each oil shale zone.

ॠUSGS 
Slide 29

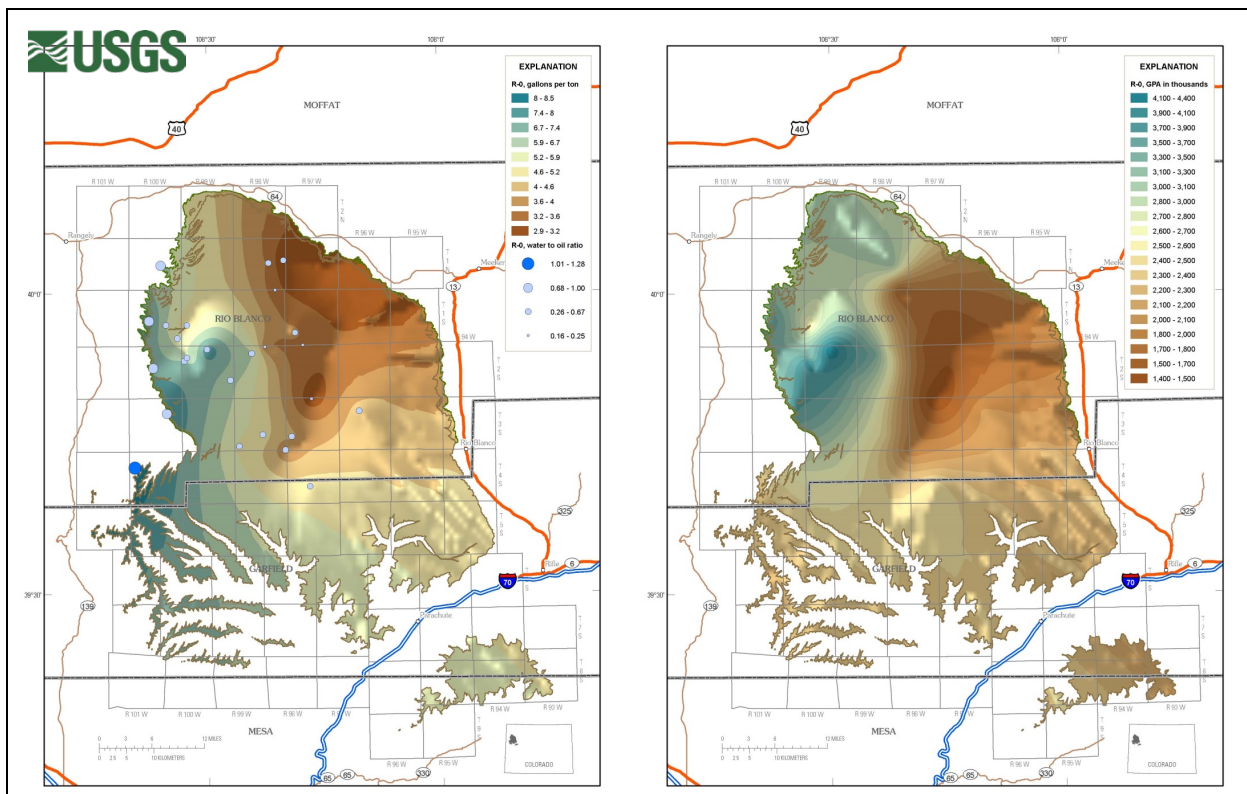

For the R-0 zone, both gallons per ton water (left) and barrels per acre water (right) increase to the west and south. The ratio of water to oil is less than one for all but one core hole. Illite is probably the dominant water-bearing mineral phase throughout the illitic interval (R-0 through L-1).

The ratio of water generated by Fischer assay and oil generated by Fischer assay is represented by bubbles on each of the gallons per ton water maps. The ratio of water needed for retorting a ton of oil shale compared to oil generated per ton of oil shale is a commonly used ratio in estimating water needed to develop an oil shale industry (Boak and Mattson, 2009) 
Slide 30
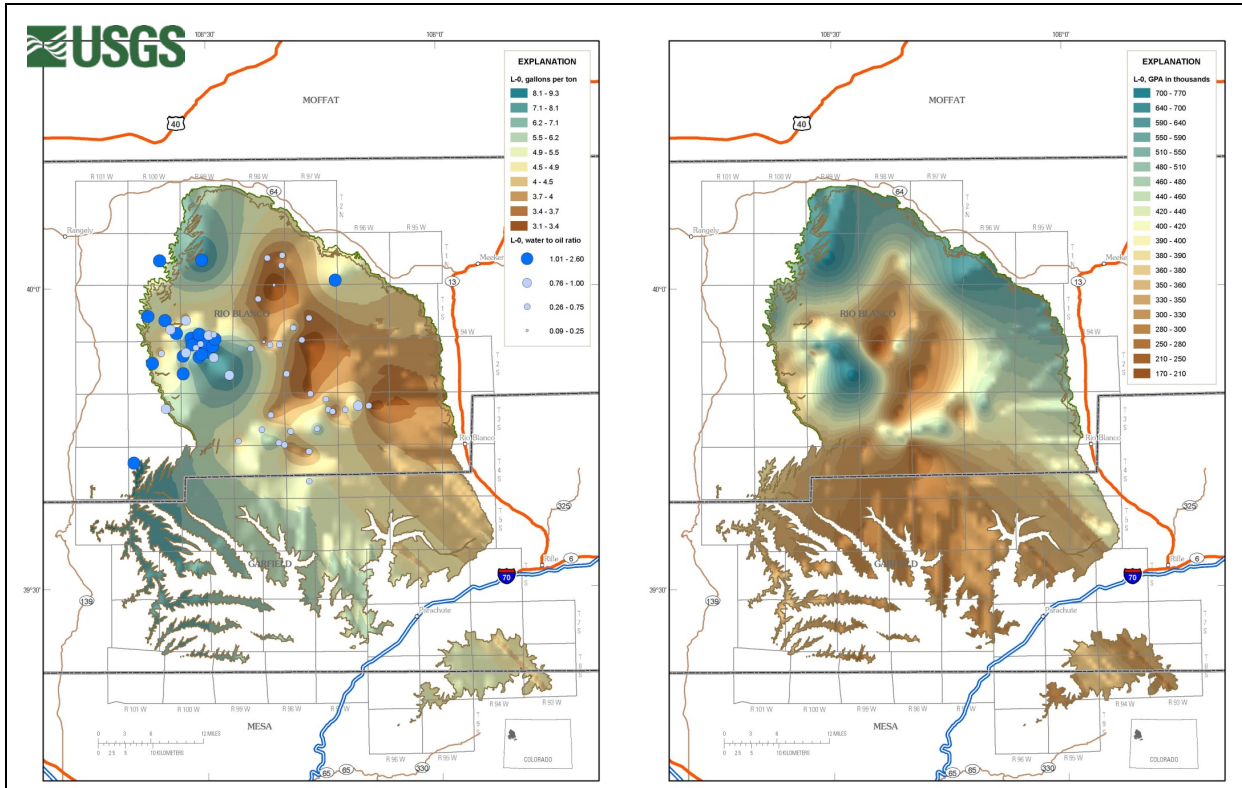

Distribution of water in the comparatively thin and lean L-0 zone is highly variable with gallons per ton water increasing to the west and south and gallons per acre water increasing to the northeast and northwest. The ratio of water to oil is greater than one along the western margin of the basin. 
Slide 31

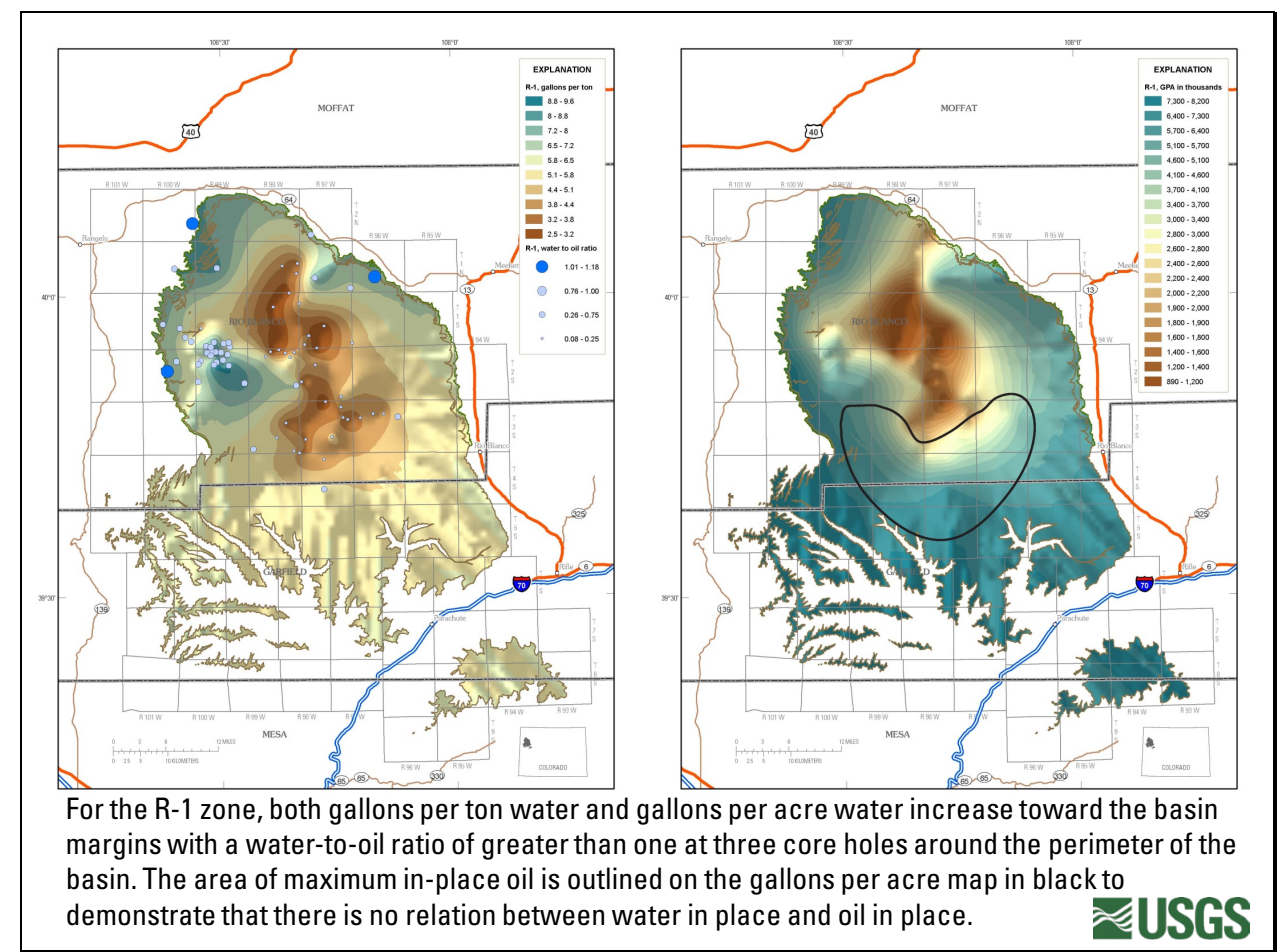


Slide 32

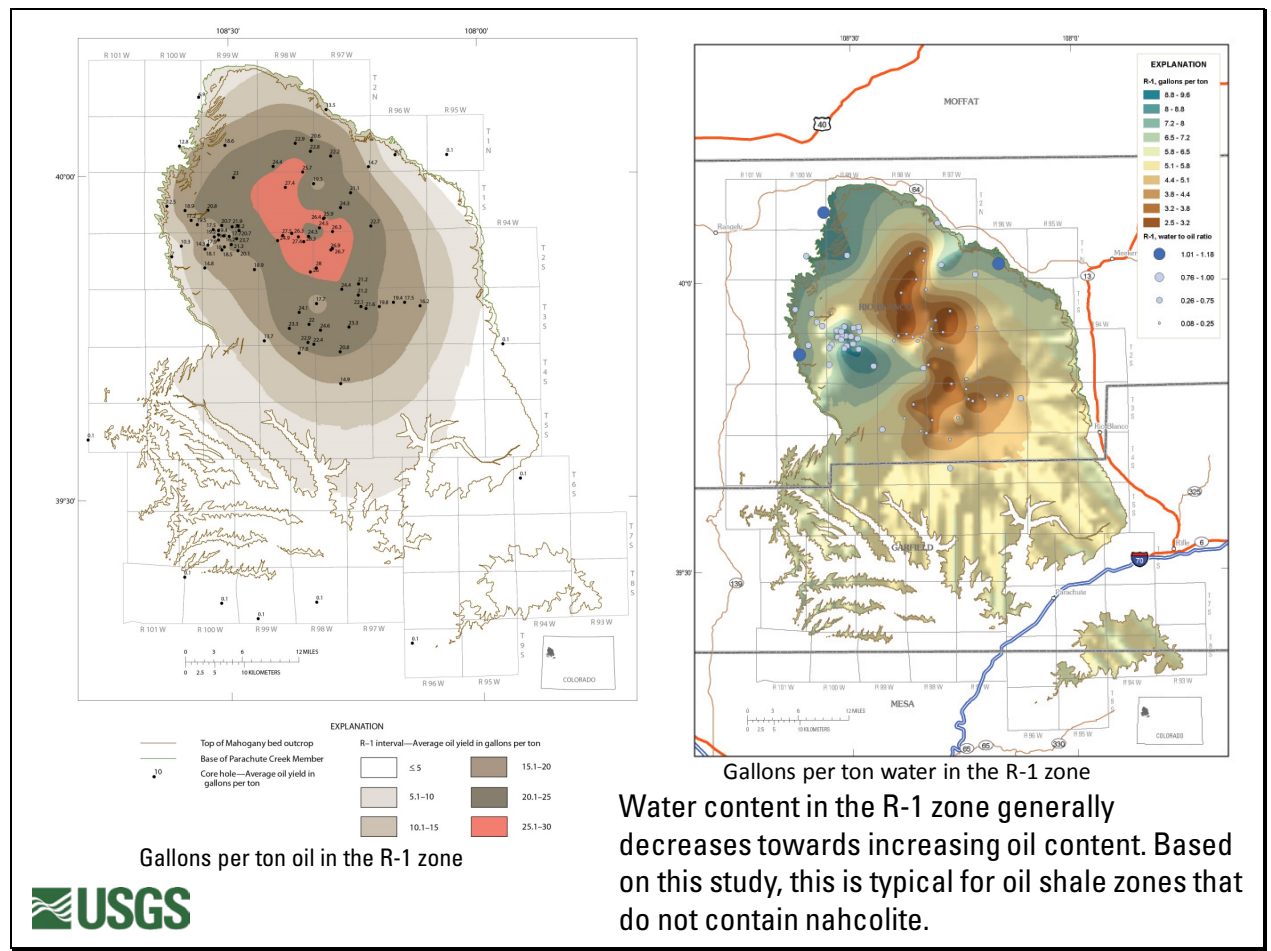


Slide 33

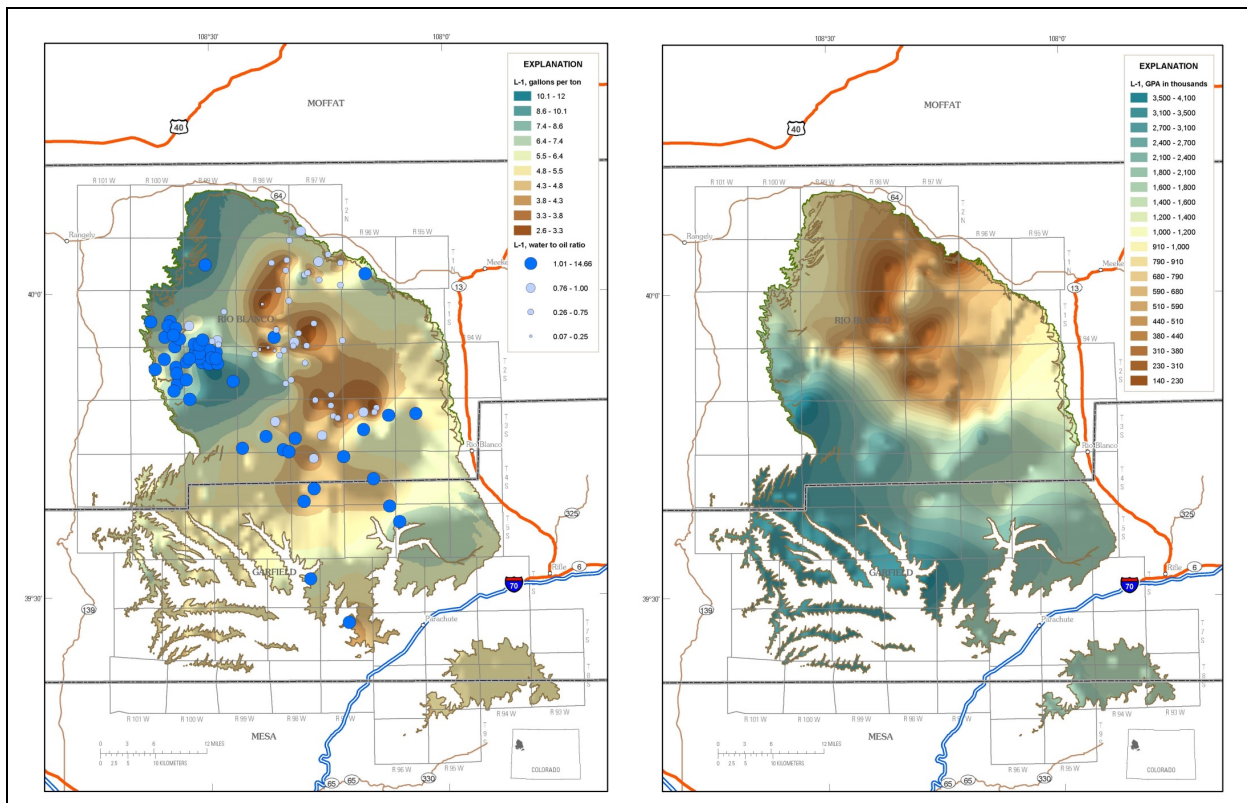

For the L-1 zone, gallons per ton water increases toward the basin margins with water to oil ratios of greater than one throughout much of the basin. Gallons per acre water increases toward the south. 
Slide 34

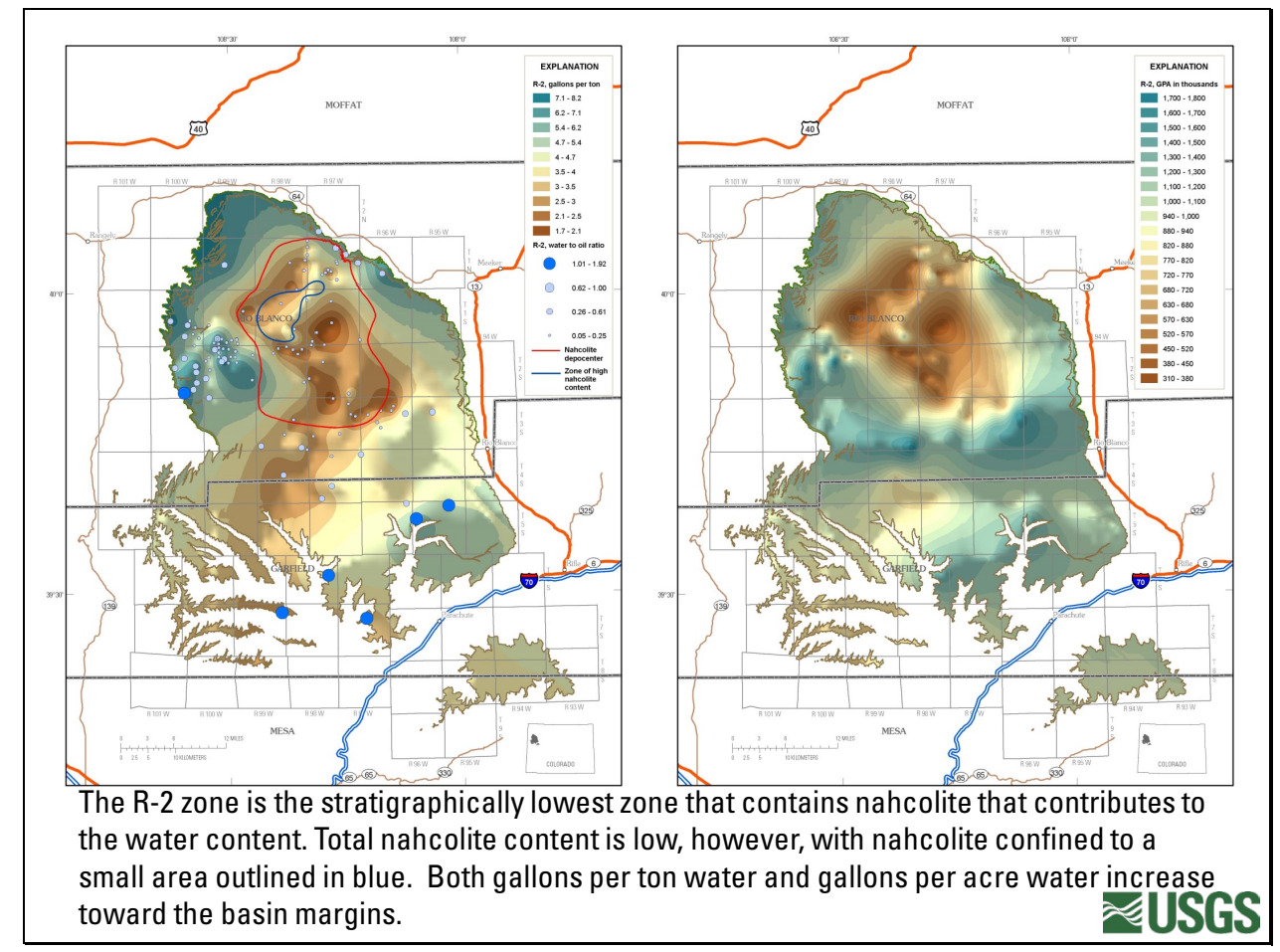


Slide 35

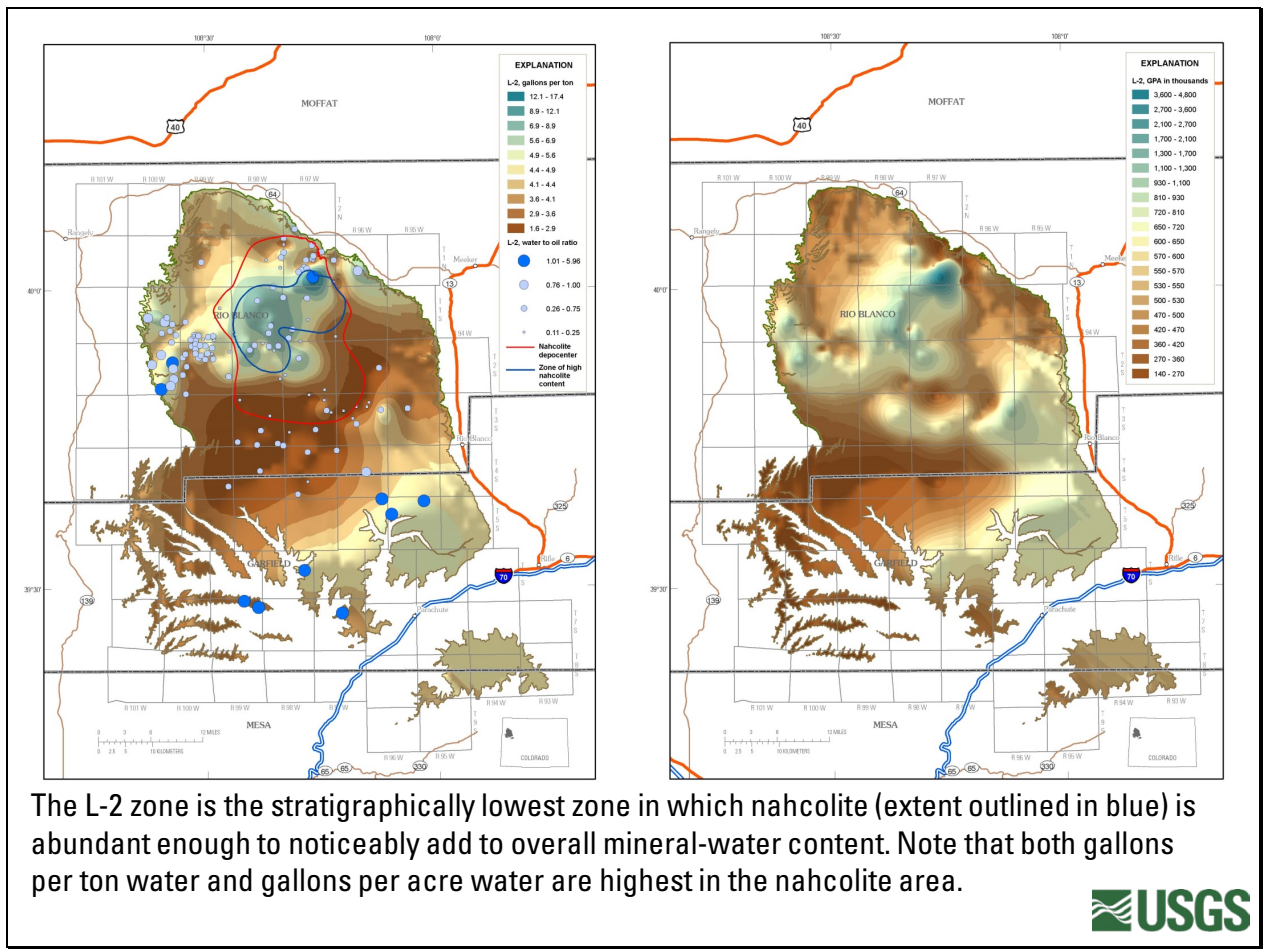


Slide 36

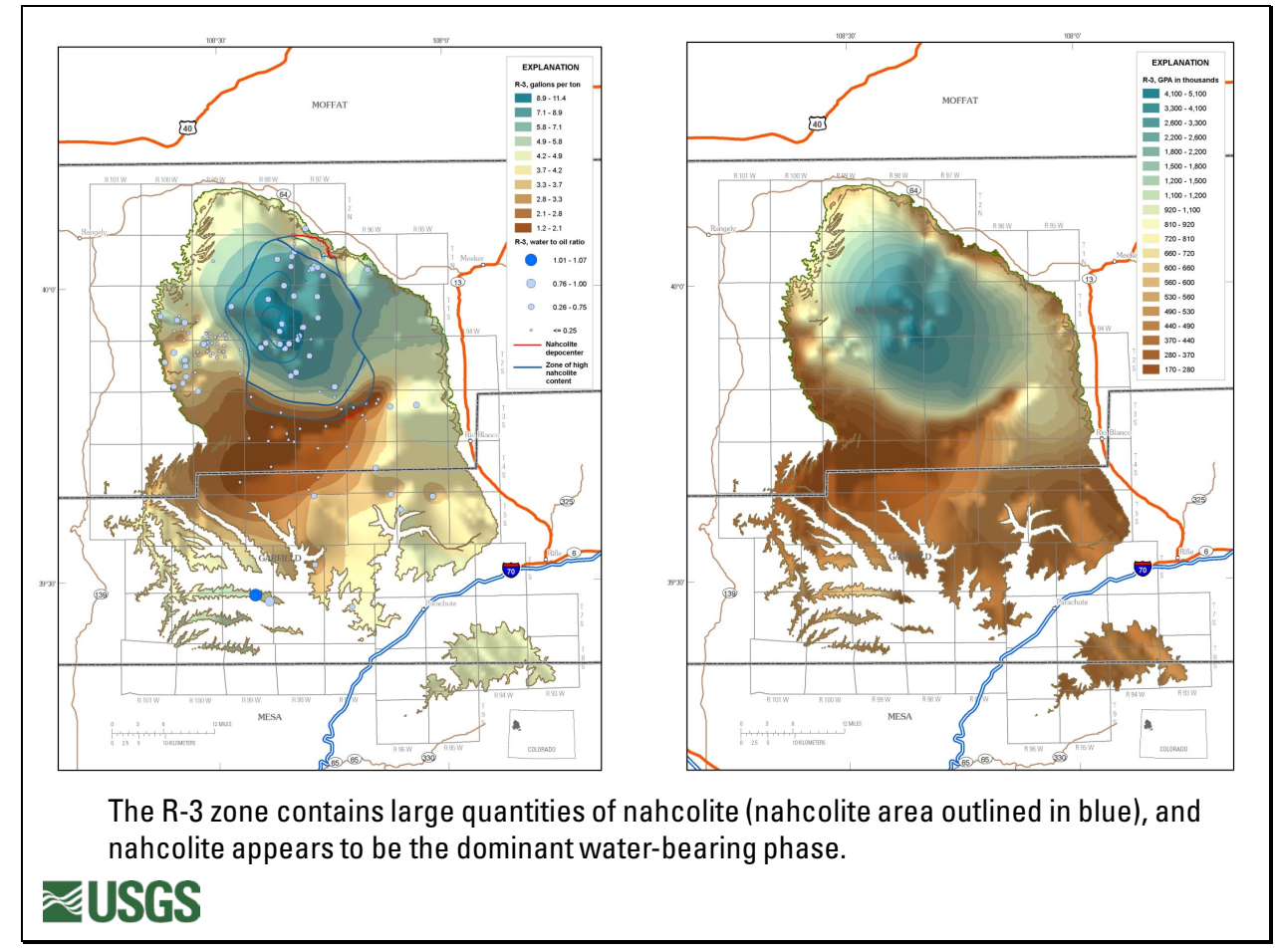


Slide 37

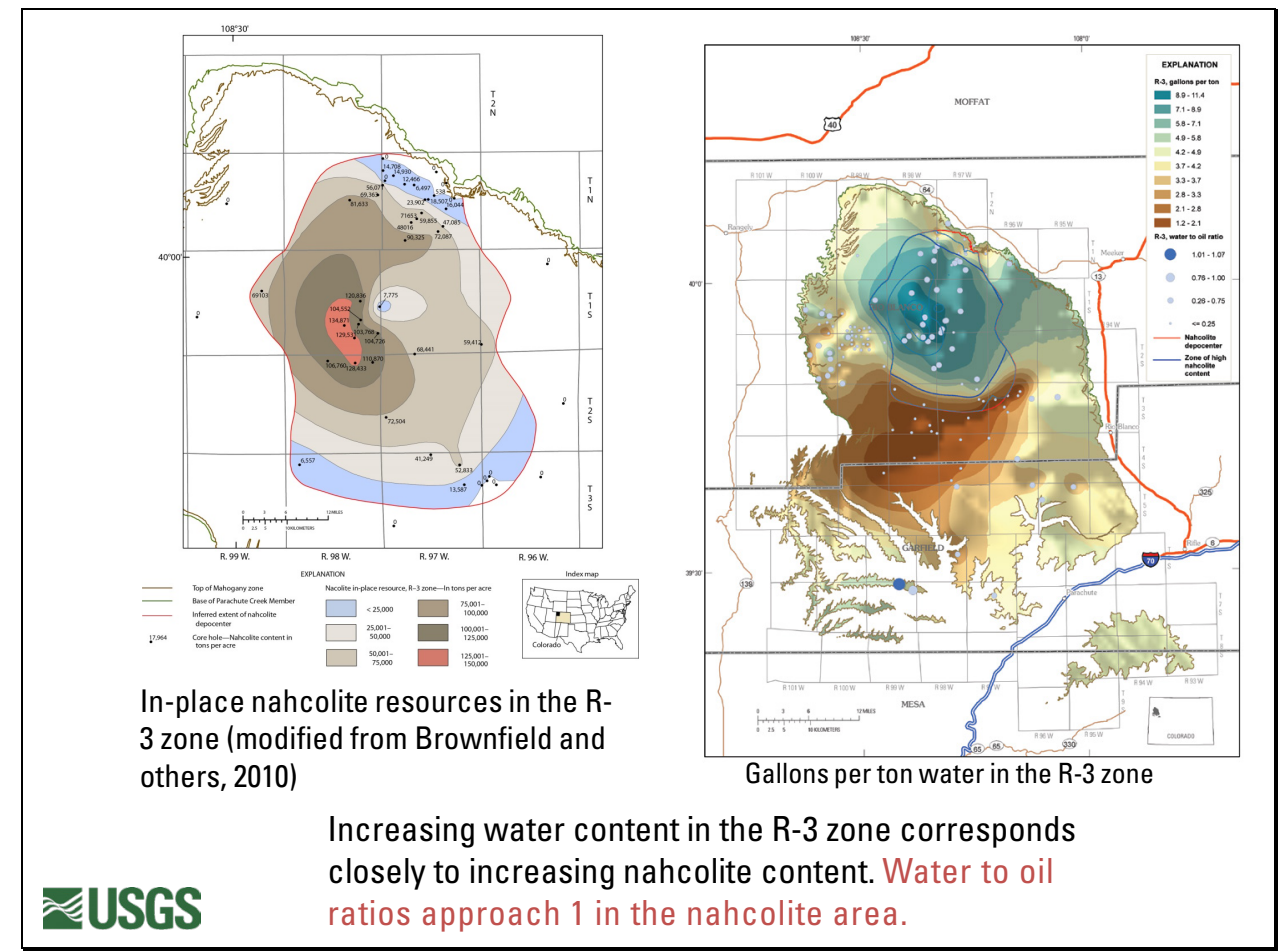


Slide 38

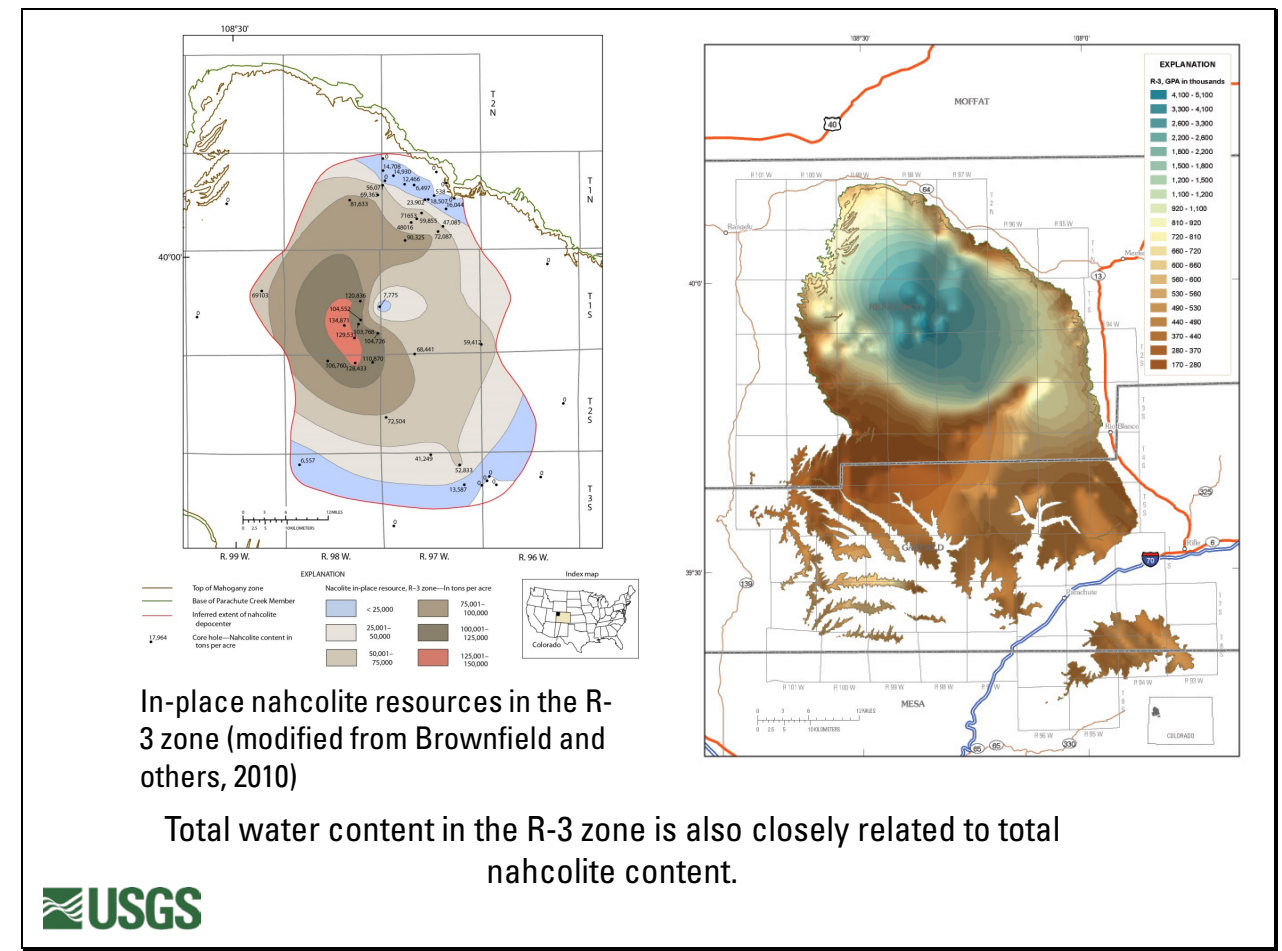


Slide 39

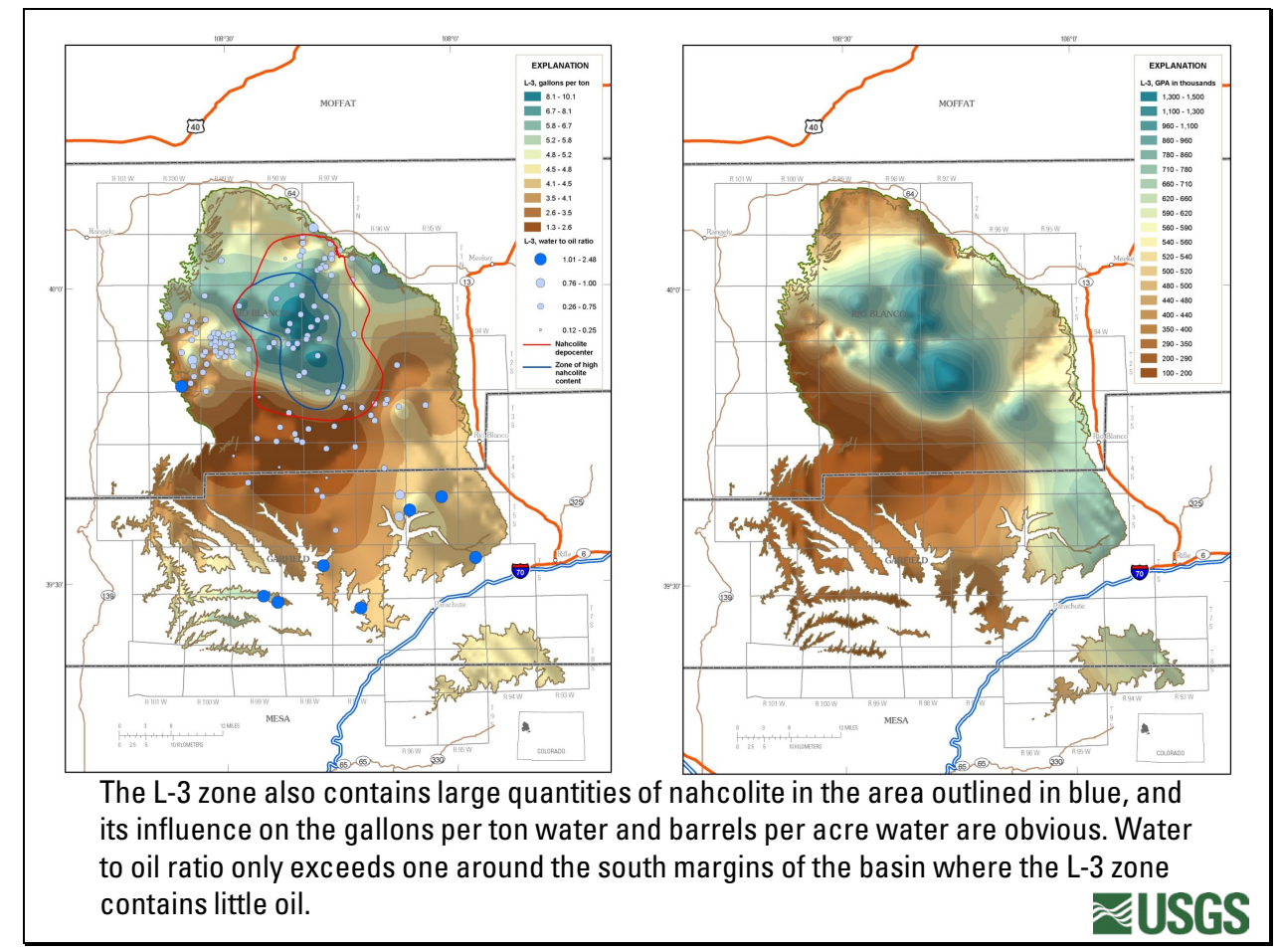


Slide 40

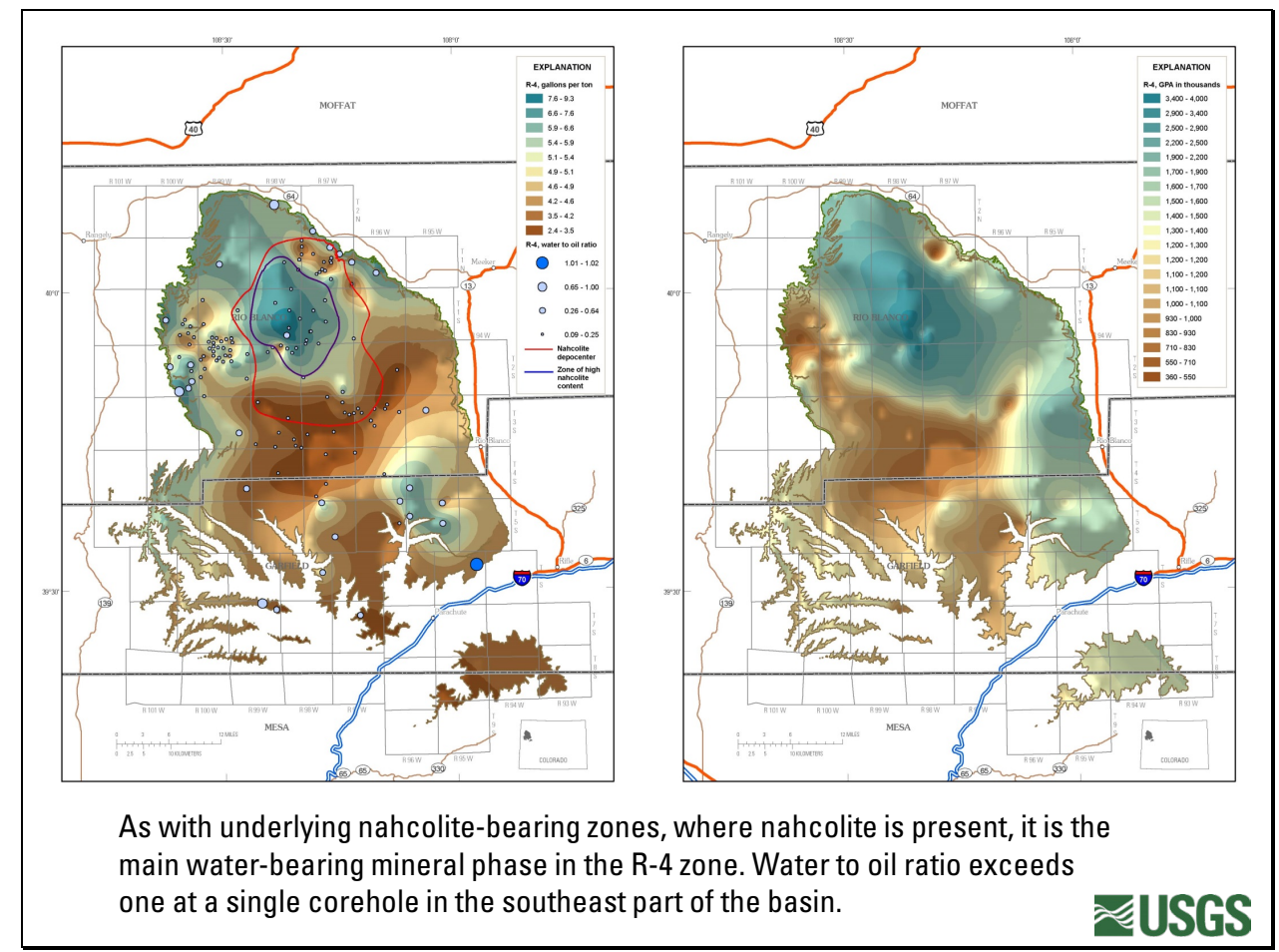


Slide 41

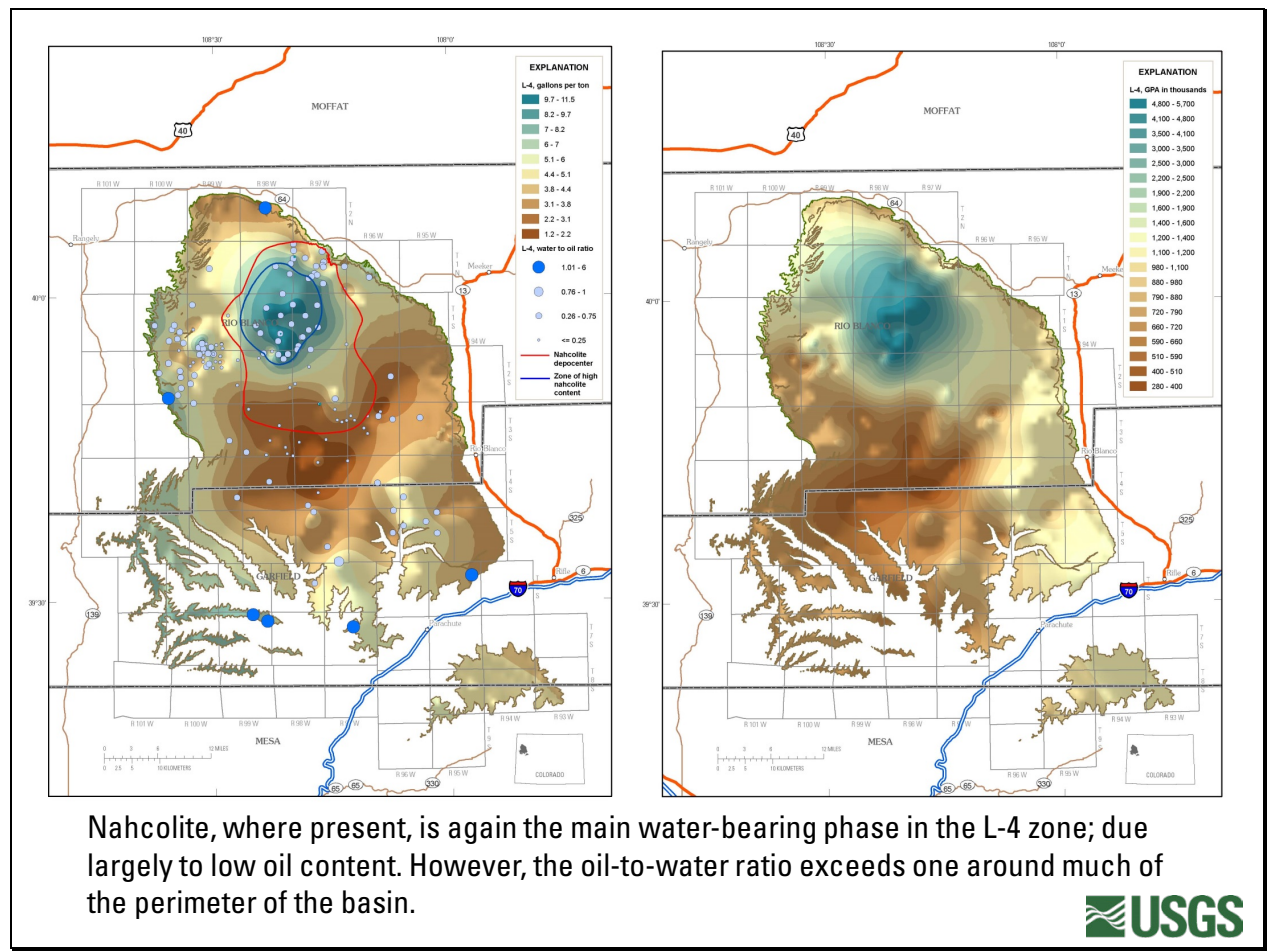


Slide 42
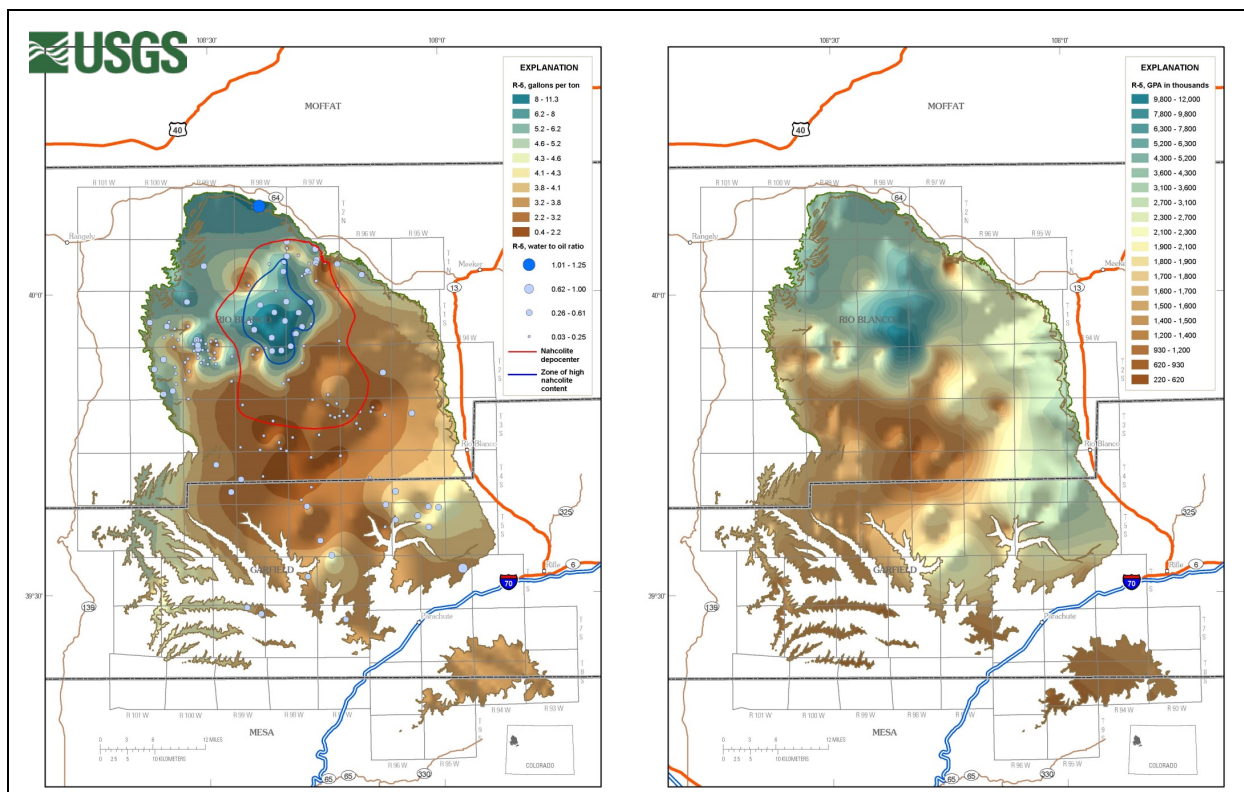

The area where nahcolite is present in the R-5 zone is smaller than in underlying nahcolitebearing zones due to the incursion of groundwater and the resultant dissolution of nahcolite around the perimeter of the original nahcolite-bearing area. The effect of nahcolite on gallons per ton and gallons per acre water is still apparent where nahcolite is not leached. 
Slide 43

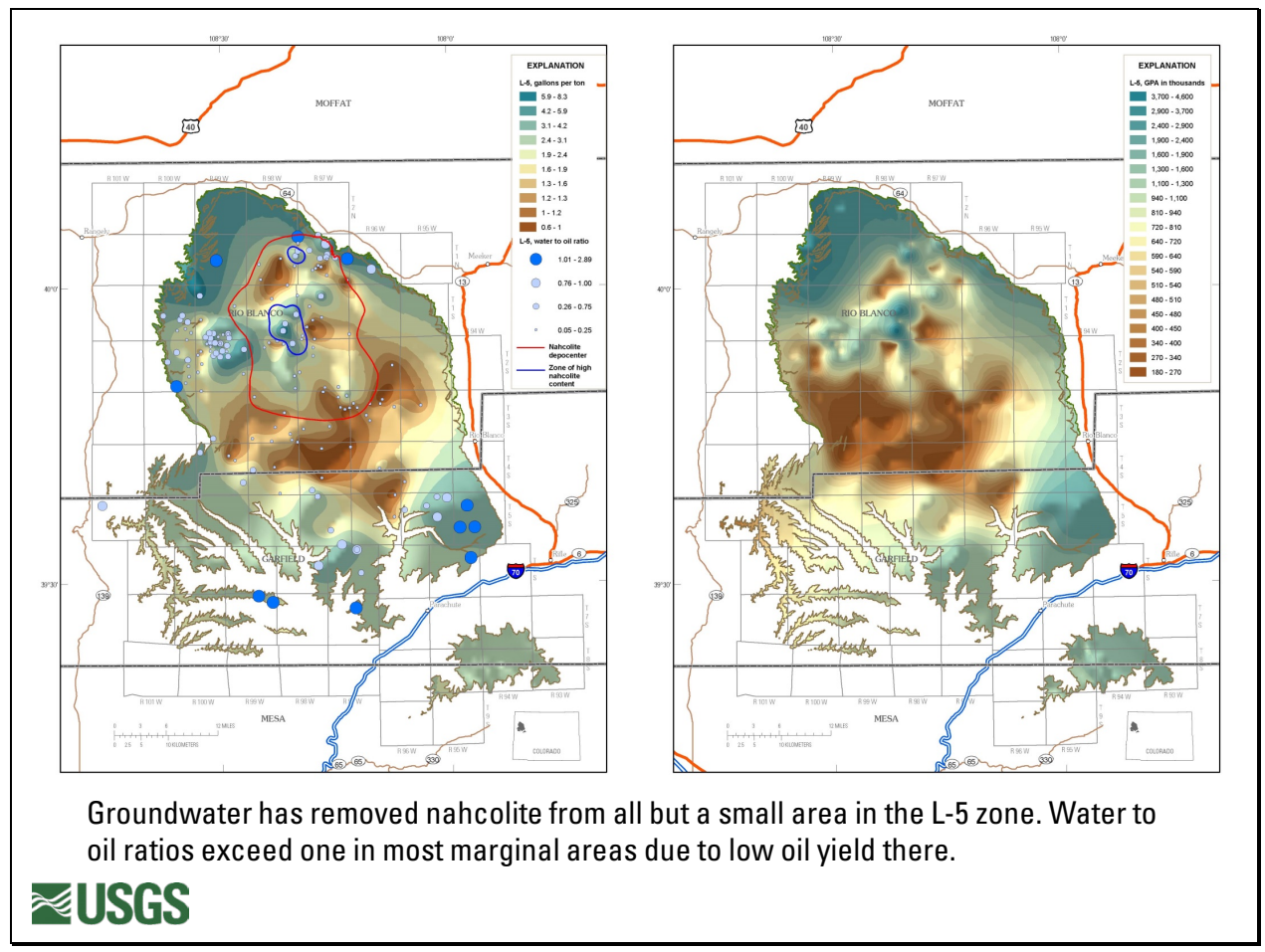


Slide 44

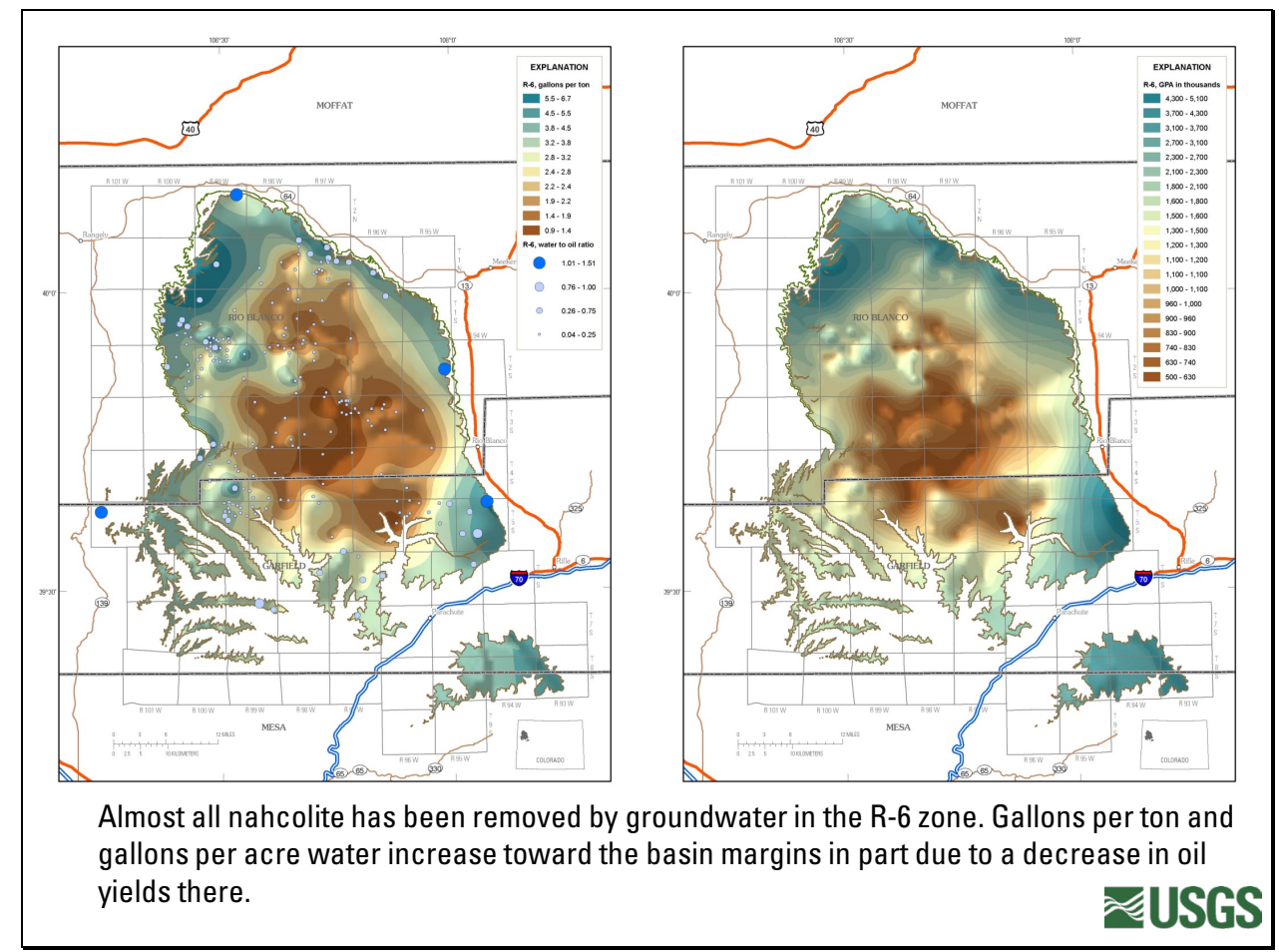


Slide 45

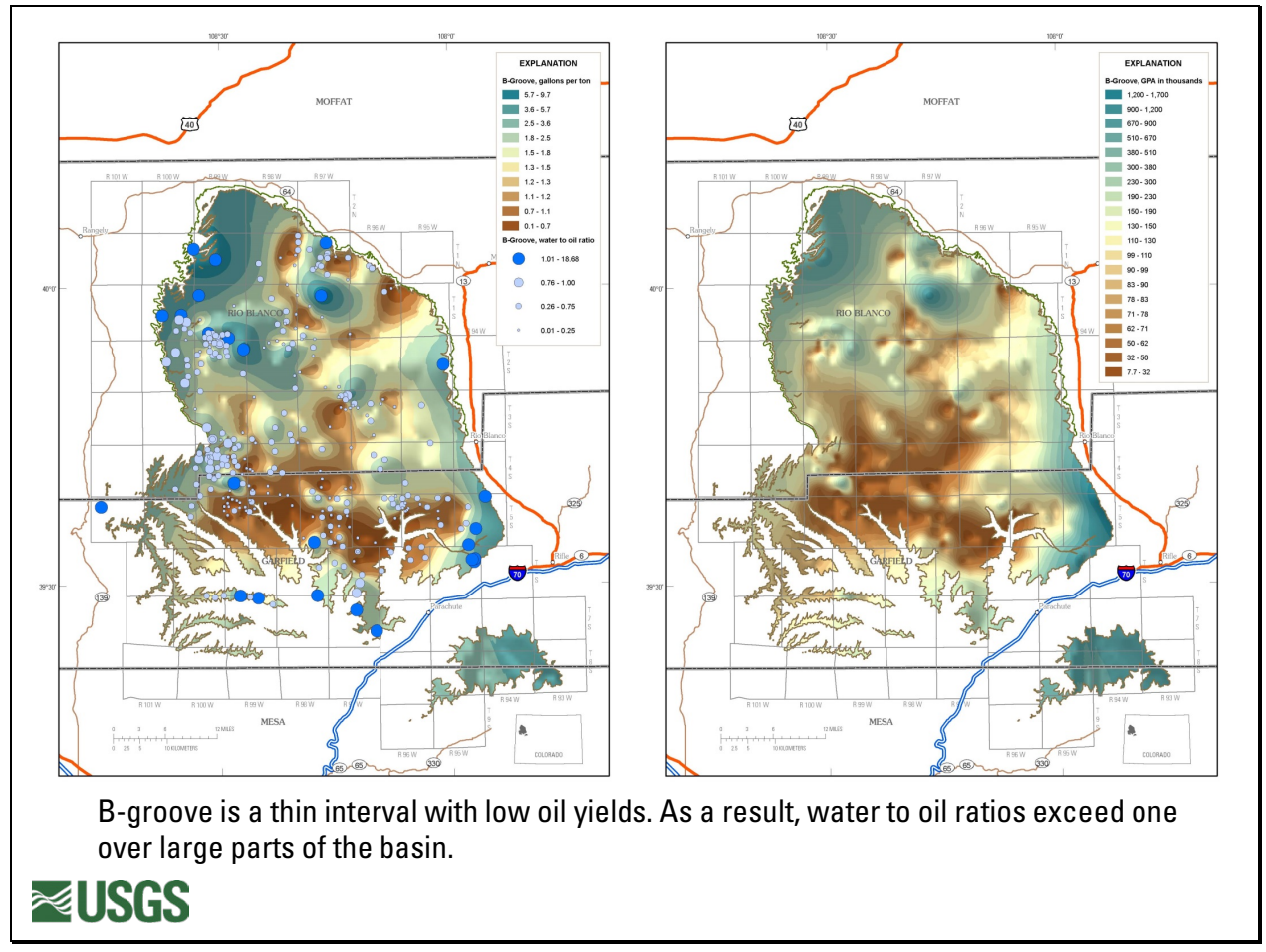


Slide 46

By Mahogany time, Lake Gosiute had largely filled in.

Outflow from Lake Gosiute caused Lake Uinta to expand and the area of oil shale deposition to expand to near the mountain fronts.

Volcaniclastic sediment reached the north shore of Lake Uinta late in Mahogany time, signaling the final infilling of Lake Gosiute.

Paleogeographic map during deposition of the Mahogany zone of the Parachute Creek

Member of the Green River Formation is from Johnson (1985).

Paleogeographic map during the Hartt Cabin bed of the Laney Member of the Green River Formation is from Roehler (1993).

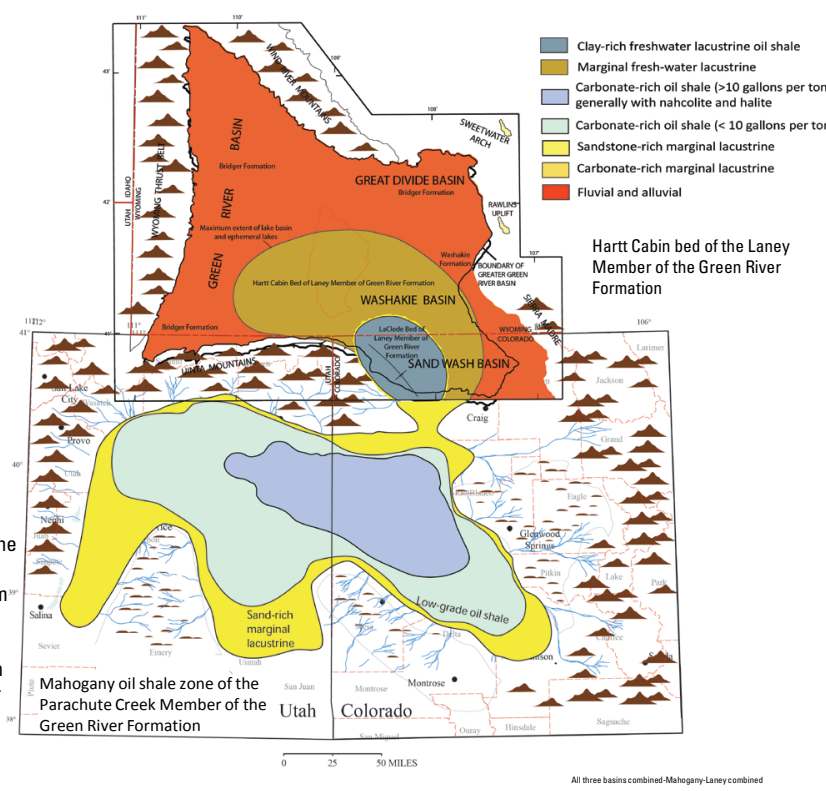


Slide 47

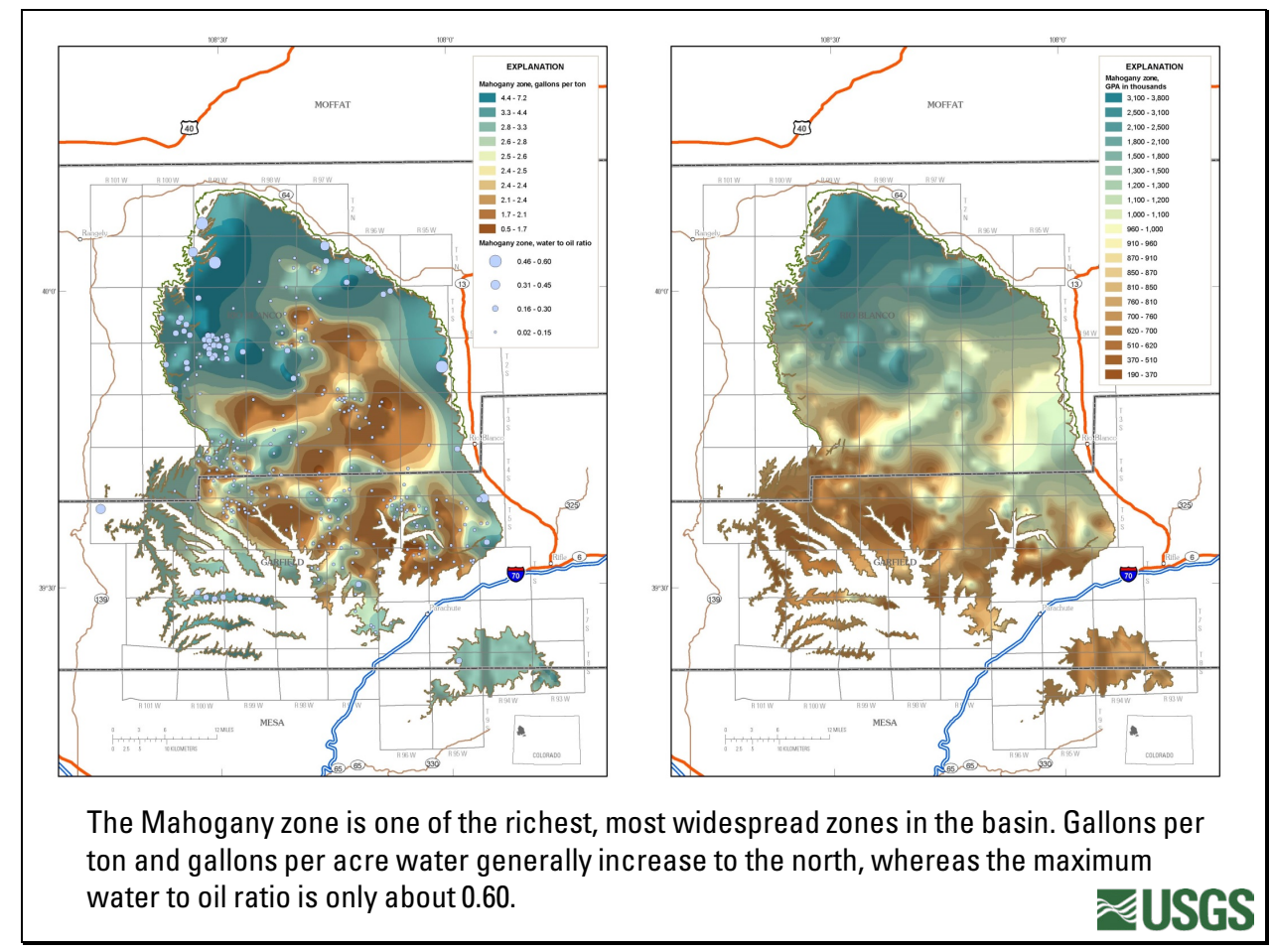


Slide 48

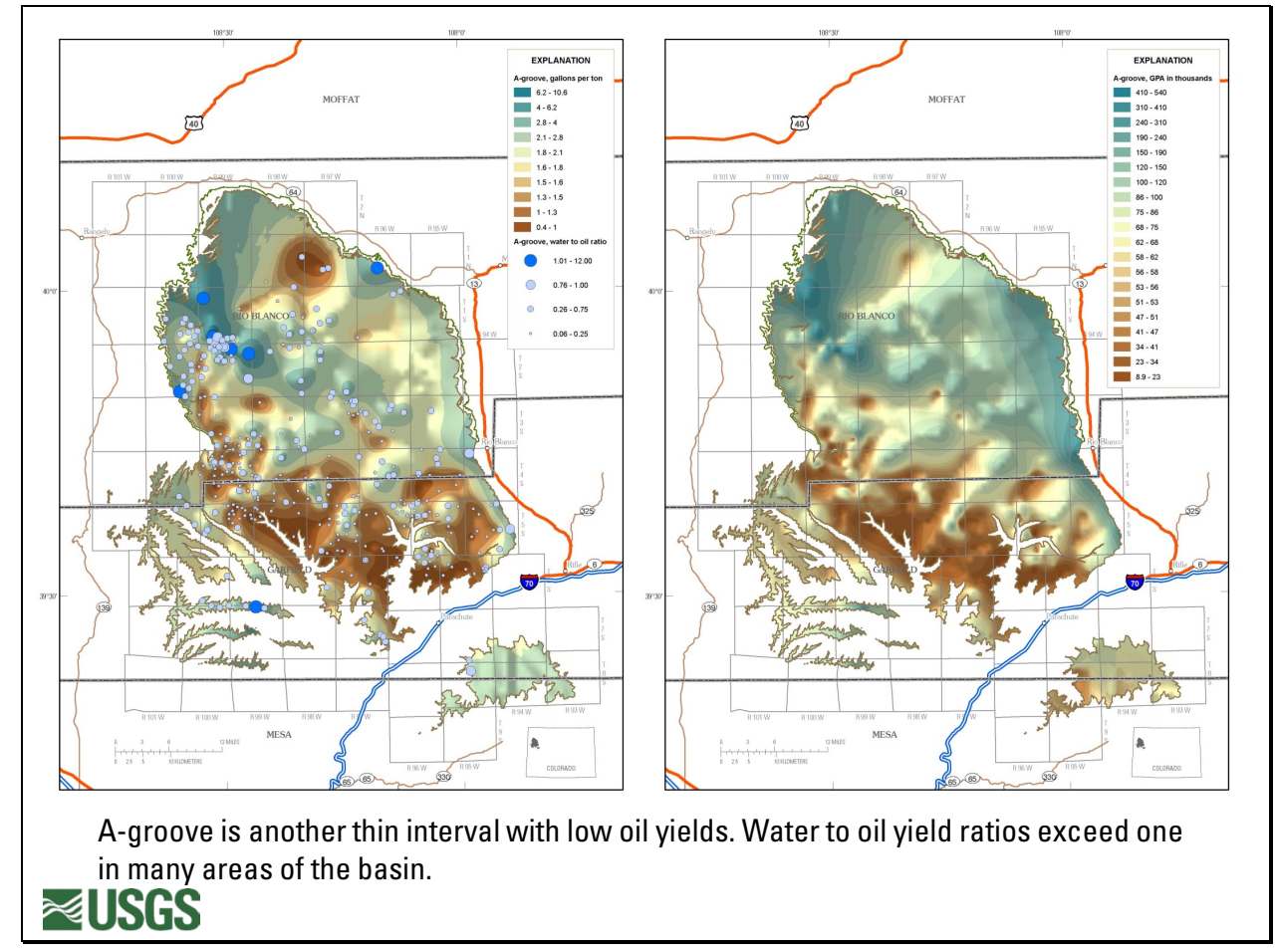


Slide 49

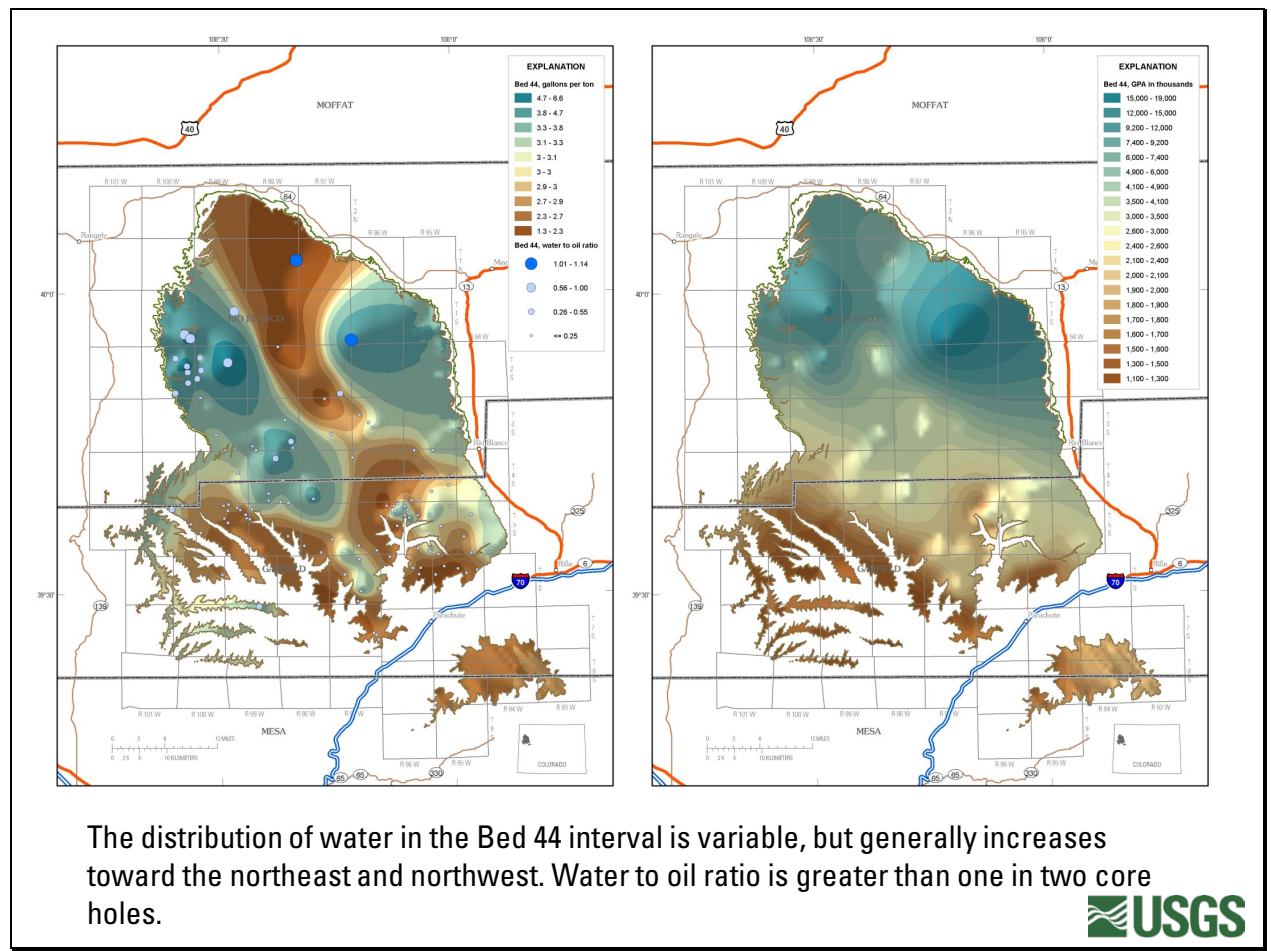


Slide 50

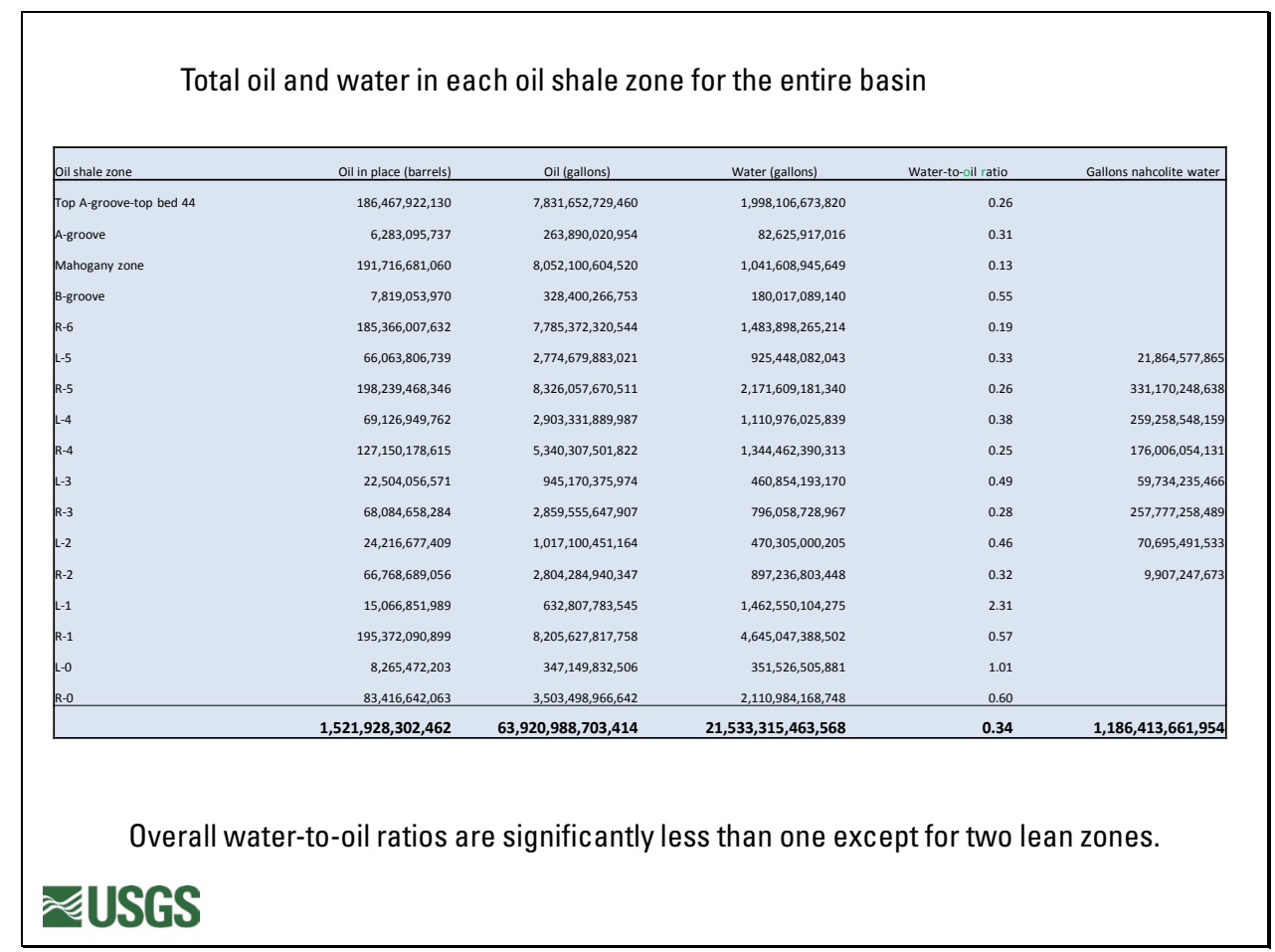


Slide 51

\section{Conclusions}

- Clay, mainly illite, is the most important source of water in the lower, illite rich part of the oil shale interval (R-0 through $L-1$ zones) and throughout the Green River Formation in basin margin areas.

- Nahcolite and dawsonite are the dominant sources of water in the oil shale and saline mineral depocenter.

- Analcime is an important source of water in the upper part of the Parachute Creek Member in the central part of the basin and throughout that member in basin-margin areas.

₹USGS 


\section{Conclusions}

- Organic matter does not appear to be a major source of water. Water content is, in general, inversely related to oil content in non-nahcolitebearing zones suggesting that organic-matter is diluting water-bearing phases.

- The ratio of water-to-oil generated with retorting is significantly less than one for most areas of the basin and for most stratigraphic intervals; therefore, water within oil shale can provide only a fraction of the water needed for an oil shale industry.

ÆUSGS 
Slide 53

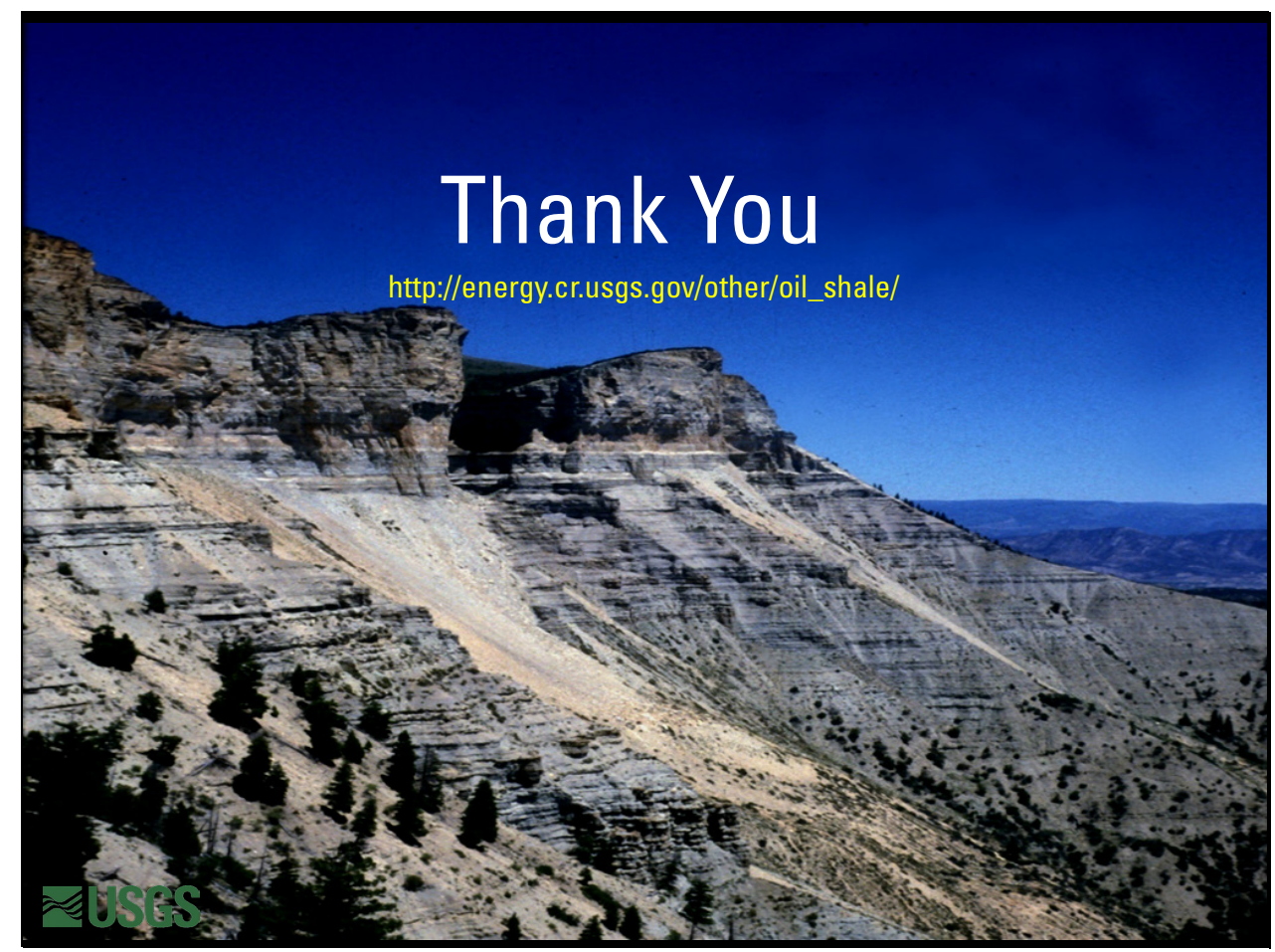


Slide 54

\section{References Cited}

- Beard, T.N., Tait, D.B., and Smith, J.W., 1974, Nahcolite and dawsonite resources in the Green River Formation, Piceance Creek Basin, Colorado, in Murray, D. Keith, ed., Guidebook to the Energy Resources of the Piceance Creek Basin, Colorado: Denver, Colo., Rocky Mountain Association of Geologists Field Conference, 25th, p. 101-110.

- Boak, J.M., 2012, A second look at water use for in situ shale oil production: Oil Shale Symposium, 32th, Golden, Colo., October 15-19, 2012, Colorado School of Mines, abstract and presentation.

- Brownfield, M.E., Mercier, T.J., Johnson, R.C., and Self, J.G., 2010, Nahcolite resources in the Green River Formation, Piceance Basin, Colorado: Oil shale and nahcolite resources of the Piceance Basin, Colorado, U.S. Geological Survey Digital Data Series DDS-69-Y, chap. 2, 51 p.

- Cashion, W.B., and Donnell, J.R., 1972, Chart showing correlation of selected key units in the organic-rich sequence of the Green River Formation, Piceance Creek Basin, Colorado, and Uinta Basin, Utah: U.S. Geological Survey Oil and Gas Investigations Chart OC-65. 
Slide 55

\section{References Cited}

- Colburn, T.T., Oh, M.S., Crawford, R.W., and Foster, K.G., 1989, Water generation during pyrolysis of oil shales-sources: Energy and Fuels, v. 3, chap. 1, p. 216-223.

- Dyni, J.R., 1974, Stratigraphy and nahcolite resources of the saline facies of the Green River Formation, Rio Blanco County, Colorado: in Murray, D.K., ed., Energy resources of the Piceance Creek Basin, Colorado, 25th Field Conference: Rocky Mountain Association of Geologists, p. 111-122.

- Johnson, R.C., 1985, Early Cenozoic history of the Uinta and Piceance Creek basins, Utah and Colorado, with special reference to the development of Eocene Lake Uinta, in Flores, R.M., and Kaplan, S.S., eds, Cenozoic Paleogeography of the West-Central United States, Rocky Mountain Paleography Symposium 3: The Rocky Mountain Section, Society of Economic Paleontologists and Mineralogists p. 247-276.

\section{ఇUSGS}


Slide 56

\section{References Cited}

- Johnson, R.C., 2012, The systematic geologic mapping program and a quadrangleby-quadrangle analysis of the time-stratigraphic relations within the oil shalebearing rocks of the Piceance Basin, western Colorado: U.S. Geological Survey Scientific Investigations Report 2010-5041.

- Johnson, R.C., Mercier, T.J., Brownfield, M.E., Pantea, M.P., and Self, J.G., 2010a, An assessment of in-place oil shale resources of the Green River Formation, Piceance Basin, Colorado: Oil Shale and Nahcolite Resources of the Piceance Basin, Colorado, U.S. Geological Survey Digital Data Series DDS-69-Y, chap. 1, 187 p.

- Johnson, R.C., Mercier, T.J., Brownfield, M.E., and Self, J.G., 2010b, Assessment of in-place oil shale resources of the Eocene Green River Formation, Uinta Basin, Utah and Colorado: Oil Shale Resources of the Uinta Basin, Utah and Colorado, U.S. Geological Survey Digital Data Series DDS-69-BB, chap. 1, 153 p.

- Johnson, R.C., Mercier, T.J., Brownfield, M.E., and Self, J.G., 2011, Assessment of inplace oil shale resources in the Eocene Green River Formation, Greater Green River Basin, Wyoming, Colorado, and Utah: U.S. Geological Survey Digital Data Series DDS-69-DD, chap. 1,63 p.

₹USGS 
Slide 57

\section{References Cited}

- Johnson, R.C. and Brownfield, M.E., 2013, Nahcolite and halite deposition through time during the saline mineral phase of Eocene Lake Uinta, Piceance Basin, western Colorado: U.S. Geological Survey Open-File Report 2013-1114, 71 annotated Power Point slides.

- Mercier, T.J., and Johnson, R.C., 2012, Isopach and isoresource maps for oil shale deposits in the Eocene Green River Formation for the combined Uinta and Piceance Basins, Utah and Colorado: U.S. Geological Survey Scientific Investigations Report 2012-5076, 85 p., 1 pl.

- Robb, W.A., and Smith, J.W., 1974, Mineral profile of oil shales in Colorado core hole no. 1, Piceance Creek Basin, Colorado, in Murray, D. Keith, ed., Guidebook to the energy resources of the Piceance Creek Basin, Colorado: Denver, Colo., Rocky Mountain Association of Geologists Field Conference, 25th, p. 81-100.

- Roehler, H.W., 1993, Eocene climates, depositional environments, and geography, Greater Green River Basin, Wyoming, Utah and Colorado: U.S. Geological Survey Professional Paper 1506-F, 74 p.

\section{ॠUSGS}

